\title{
QUALIDADE FISIOLOGICA E SANITARIA \\ DE SEMENTES DE ERVILHA TRATADAS COM FUNGICIDA
}

WARREY OHARCOSS DNASTCOMEOVUD

Engenheiro-Agronomo

Orientador: Prof. Dr. Silvio Moure Gicero

\begin{abstract}
Dissertacão apresentada à Escola superior de Agricultura lluiz de queiroz". da universidado de são paulo. para oblencão do titulo de Mestre em Agronomia, Área de concentracão: Filotecnia.
\end{abstract}

$P I R A C I C A B A$

Estado de São Paulo - Brasil

Abril - 1990 
Ficha catalográfica preparada pela Seção de Livros da Divisão de Biblioteca e Documentação - PCAP/USP

Nascimento, Warley Marcos

N244q Qualidade fisiológica e sanitária de sementes de ervilha tratadas corn fungicida. Piracicaba, 19.90. $97 p$.

Diss.(Mestre) ESALQ

Bibliografia.

1. Ervilha - Semente - Qualidade 2. Ervilha - Se mente - Tratamento fungicida I. Escola Superior de Agricultura Luiz de Queiroz, Piracicaba

$\operatorname{CDD} 635.656$ 
QUALIDADE FISIOLOGICA E SANITARIA

DE SEMENTES DE ERVILHA TRATADAS COM FUNGICIDA

WARREIT MARCOOS ONASCODYEONTO

Aprovada em: 11.05 .90

Comissão julgadora:

Prof. Dr. Silvio Moure Cicero ............ ESALQ USP

Prof. Dr. Júlio Marcos Filho .......................

Prof. Dr. José Otávio Machado Menten .......... ESALQ USP

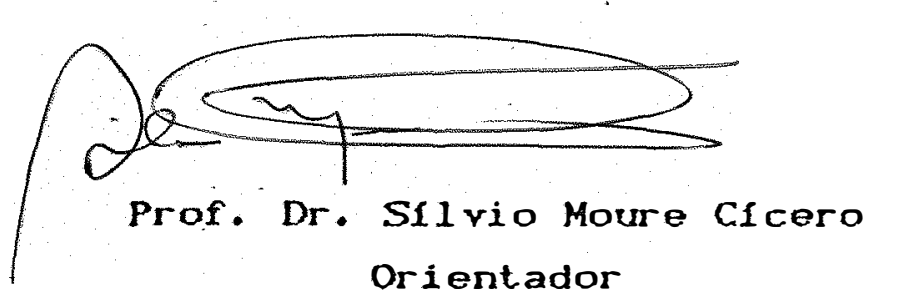


ii.

$\dot{A}$

Anna Christina,

Fabiana e

Andressa. 


\section{AGRADECIMENTOS}

Ao Professor Silvio Moure Cicero, pela amizade, orientação e dedicaçăo durante a conduçăo do trabalho.

\section{Aos Professores Júlio Marcos Filho e Jose} Otávio Machado Menten pelas valiosas sugestð̈es apresentadas no transcorrer do presente trabalho.

Aos Engenheiros Agronomos Ana Dionisia da Luz Coelho Novembre, Helena M.C. P. Chamma, José Eustáquio de Menezes e Maria Heloisa Duarte de Moraes, pela colaboraçăo prestada na conduçăo dos testes de laboratório e de campo.

Á Elisete A. Marcos, pelo auxilio na execução da análise estatistica.

Ao Centro Nacional de Pesquisa de Hortaliças da EMBRAPA pela oportunidade de realizaçăo do curso.

À Coordenaçăo de Aperfeiçoamento de Pessoal de Nivel Superior, pela bolsa de estudos concedida.

Aos Serviço de Produção de Sementes Básicas da EMBRAPA, e Companhia Asgrow do Brasil Sementes Ltda. pelo fornecimento das sementes utilizadas na pesquisa.

Aos Professores e funcionários do Departamento de Agricultura pelas facilidades proporcionadas no transcorrer da pesquisa.

Aos colegas de curso, pela amizade e incentivos. 
iv.

SUMARIO

Página

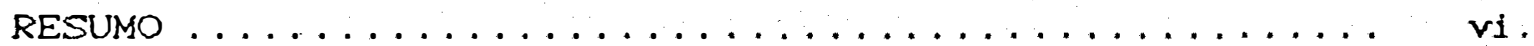

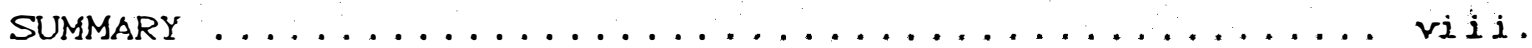

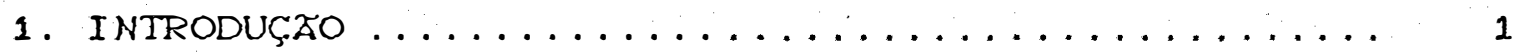

2. REVISÃO DE LI TERATURA .................. 3

2.1. Microorganismos Associados às Sementes de Ervilna .....................

2.2. Doenças e Danos Causados por Microorganismos Associados às Sementes de Ervilhas ........... 4

2. 3. Cultivares e Resistência à Doenças ........... 10

2. 4. Fungicidas: Controle de Microorganismos...... 12

2.5. Fungicidas: Efeito na Qualidade das Sementes. 15

2. 6. Armazenamento ..................... 19

3. MATERI AL E METODOS ..................... 23

3.1. Sementes e Cultivares ............... 23

3. 2. Tratamentos Fungicidas .............. 24

3. 3. Armazenamento .................... 25

3. 4. Avali ação da Qualidade das Sementes ......... 25

3. 4.1. Germinaçăo ................. 26

3. 4.2. Primeira contagem de germinação ...... 27

3. 4. 3. Envel hecimento acelerado ......... 27

3. 4. 4. Condutividade eletrica ........... 28

3. 4.5. Emergéncia das plantulas em campo .... 28

3. 4. 6. Determinaçăo do grau de umidade...... 31

3. 4.7. Sanidade das sementes ........... 32

3.5. Procedimento Estatistico ............ 37 
Página

4. RESUltados E discusssto ................. 35

4.1. Cultivar Mikado ................. 35

4.1.1. Germinação ................... 35

4.1.2. Primeira contagem de germinação...... 39

4.1.3. Envel hecimento acelerado .......... 42

4.1.4. Condutividade elétrica ........... 45

4.1.5. Emergéncia das plantulas em campo ..... 48

4.1.6. Determinação do grau de umidade ...... 51

4.1.7. Sanidade das sementes ........... 53

4.1.7.1. Lote MA ........... 53

4.1.7.2. Lote $M B \ldots \ldots \ldots \ldots \ldots \ldots$

4.2. Cultivar Pomak ...................... 60

4.2.1. Germina̧̧ฐ̃o ....................... 62

4.2. 2. Primeira contagem de germinação ....... 64

4. 2. 3. Envel hecimento acelerado ........... 66

4.2. 4. Condutividade elétrica ............ 69

4.2.5. Emergência das plantulas em campo .... 71

4.2.6. Determi nação do grau de umidade ...... 74

4.2.7. Sanidade das sementes ............ 75

4.2.7.1. Lote PA ............. 78

4.2.7.2. Lote $P B \ldots \ldots \ldots \ldots$

4. 3. Consideraçbes Finais ................ 81

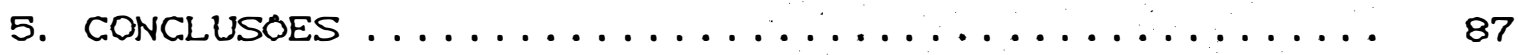

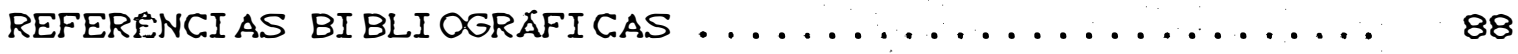


QUALIDADE FISI OLOGICA E SANITARIA

DE SEHENTES DE ERVILHA TRATADAS COM FUNGICIDA

\begin{abstract}
Autor: Warley Marcos Nascimento
Orientador: Silvio Moure Cicero.
\end{abstract}

RESUMO

A utilização de fungicidas para tratamento de sementes, visando a preservação da qualidade durante o armazenamento, e a proteçăo por ocasião da emergéncia das plantulas em campo, tem sido muito discutida; porém, poucas informaçoes a respeito destes produtos interferindo na qualidade das sementes de ervilha tem sido observadas na literatura disponivel. Por estes motivos, o presente trabal ho, conduzido no Laboratório de Análise de Sementes do Departamento de Agricultura e no Laboratório de Patologia de Sementes do Departamento de Fitopatologia, ambos da Escola Superior de Agricultura "Luiz de Queiroz", Universidade de Săo Paulo, bem como no Campo Experimental do Centro Nacional de Pesquisa de Hortaliças/EMBRAPA em Brasilia-DF; teve por objetivo avaliar os efeitos dos fungicidas Captan, Thiram, Iprodione, Benomyl e da mistura Iprodione + Thiram aplicadas em sementes de ervilha. Para tanto, avaliou-se o efeito 
vii.

destes produtos sobre a germinaçăo, primeira contagem de germinação, envelheciment.o acelerado, condutividade elet.rica, grau de umidade, sanidade das sementes e emergencia das plantulas em campo, utilizando-se quatro lotes de sementes pertencentes aos cultivares Mikado e Pomak; os testes de laboratório e de campo for am realizados em três épocas, com intervalos trimestrais, no perído de novembro de 1988 a julho de 1989. A analise dos dados e interpretação dos resultados permitiram as seguintes conclusbes: os efeitos favoraveis dós tratamentos fungicidas sobre a germinação e vigor se manifestaram principalmente nas sementes de menor qualidade fisiológica; as tendencias de efeitos fitotóxicos às sementes causados por alguns fungicidas, observados em laboratório, foram amenizados ou mesmo suprimidos quando as mesmas estas foram semeadas em campo; a maioria dos fungicidas testados exerceu um excelente controle dos principais fungos de campo associados às sementes, bem como dos fungos de armazenamento, garantindo assim, uma melhoria na qualidade sanitária das sementes; os fungicidas de amplo espectro de ação, como laptan e Thiram, assim como a mistura Iprodione + Thiram, proporcionaram, na epoca normal de semeadura, uma maior emergéncia de plantulas em campo. 
viii.

\section{PHYSI OLOGICAL AND SANITARY QUALITY OF PEA}

SEEDS TREATED WITH FUNGICIDES

Autor: Warley Marcos Nascimento

Adviser: Sflvio Moure Clcero

SUMHEARY

The use of fungicides for seed treatment, as a mean of preserving seed quality during storage and protecthe seedling emergence, has been frequently discussed. However, published information concerning these effects on pea (Pisum sativum L.) seed is 1 imited. This research was conducted at the Seed Analysis Laboratory Departament of Agriculture, and Seed Pathology Laboratory of the Departament of Plant Pathology, Escola Superior de Agricultura "Luiz de Queiroz", University of Săo Paulo, in Piracicaba, State of Sao Paulo, and at National Center for Vegetable Research - CNPHAEMBRAPA, in Brasllia - Brazil. The trials aimed at evaluating the effect, of the fungicides Captan, Thiram, Iprodione, Benomyl and the mixture Iprodione + Thiram applied on pea seeds. The influence of these fungicides was evaluated using the following parameters: germination, first count germination, accelerated aging, 
eletrical conductivity, moisture content, seed health, and field emergence. Four seed lots (cvs. Mikado and Pomak) were evaluated under laboratory and field conditions at three dates, every three months, from November 1988 to July 1989. The data obtained indicated that: seeds with lower physiological quality were more favorably affected by the fungicide treatment; phytotoxic effects observed under laboratory conditions were minimized or absent under field conditions; most of the fungicides tested controlled the main seed borne and storage fungi associated with the seeds, thus improving the seed health characteristics; Captan, Thiram, and Iprodione + Thiram, on the usual field planting date, improved field emergence. 


\section{INTRODUSAO}

O Brasil sempre foi um tradicional importador de ervilha, tanto sementes como grãos para indústria de reidrataçăo. Com os resultados de pesquisas demonstrando a grande potenciali dade para produção desta espécie em al gumas regiöes do pals, o Brasil vem aumentando a área cultivada com esta leguminosa, atualmente estimada em 22.000 ha, em detrimento da importaçăo. Dessa forma; diminui-se a evasão de divisas para o exterior e criatse uma nova opção de cultivo de inverno para nossos agricultores.

Todavia, a produção de sementes de ervilha, considerada uma atividade recente, é apontada como um dos fatores que limitam a produção desta espécie em nosso pals. Assim, o suprimento de sementes de alta qualidade genética, física, fisiológica e sanitária torna-se uma necessidade para um maior desenvolvimento dessa cultura no Brasil.

Diversos fatores interferem na obtençăo de sementes de alta qualidade. Dentre eles, os microorganismos tem sido apontados como um dos principais causadores da redução da qualidade das sementes de ervilha.

Além disto, sabe-se que o armazenamento da semente e necessário no processo de produçăo de ervilha, 
pois o perlodo de colheita nåo concide com o momento mais adequado para a semeadura. Desta forma, a utilizaçăo de medidas que contribuam para uma melhor conservaça das sementes assume uma importåncia considerável.

Sendo assim, o tratamento de sementes de erviIha com fungicida, pode-se constituir numa pratica bastante interessante, visto que além de propiciar uma melhor conservaçăo durante o armazenamento, oferece ainda proteça na fase inicial de desenvolvimento das plantas no campo.

Entretanto, permanece a necessidade de seleçăo de fungicidas para o tratamento de sementes de ervilha nas nossas condiçres, bem como de estudos sobre o efeito destes produtos na qualidade fisiológica e sanitária das sementes durante o periodo de armazenamento e estabelecimento da cultura no campo. 
3.

\section{REVISAO DE LITERATURA}

\subsection{Microorganismos Associados às Sementes de Ervilha}

Vários são os microorganismos associados as sementes de ervilha, alguns dos quais causadores de doenças de considerável importáncia. RICHARDSON (1979) e RICHARDSON (1981) relata os seguintes microorganismos: Ascochyta spp.., incluindo Ascochyta pisi, Ascochyta pinodes e Ascochyta pinodella; Botrytis cinerea; Cladosporium cladosporioides f. sp. pisicola; Colletotrichum pisi; Erysiphe pisi; Fusarium oxysporium f. sp. pisi; Peronospora viciae; Pleospora herbarum; Rhizoctonia solani; Sclerotinia sclerotiorum; Septoria pisi; Pseudomonas phaseolicola; Pseudomonas pisi; Xanthomonas rubefaciens e os virus "Pea Early-Browning virus" e "Pea Seed-Borne Mosaic Virus".

Segundo HAGEDORN (1984), os seguintes patógenos são transmitidos elou transportados por sementes de ervilha: Ascochyta spp., Colletotrichum pisi, Cladosporium pisicolum, Erysiphe pisi, Fusarium oxysporum r. sp. pisi, Peronospora pisi, Septoria pisi, Sclerotinia sclerotiorum, Pseudomonas syringae pv. pisi, Pseudomonas syringae pv. syringae e os virus "Pea Seedborn Mosaic Virus" (PSbMV) e "Pea Early-Browning virus" (PEBV). 
AGARWAL \& SINCLAIR (1987) citaram Ascochyta pisi, Fusarium oxysporium f. sp. pisi, Phoma medicaginis var. pinodella e Pseudomonas syringae pv. pisi, como sendo os mais importantes patógenos transmitidos por sementes de ervilha, causando reduçăo na produtividade da cultura.

SANTOS (1989) descreve os fungos comprovadamente transmitidos por semente de ervilha: Ascochyta pinodella, A. pinodes, A. pisi, Ascochyta. sp., Cladosporium cladosporioides, C. pisicolum, Colletotrichum pisi, Fusarium oxysporiun f.sp. pisi, F. solani f. sp. pisi, Oidium sp., Peronospora pisi, Pleospora herbarum, Rhizoctonia solani, Rhizopus stolonifer, Rhizopus. sp., Sclerotinia sclerotiorum, Septoria flagellifera e S. pisi.

Os fungos Aspergilius spp. e Penicillium spp. foram citados por FIELDS \& KING (1962), CHRISTENSEN \& KAUFMANN (1963), CHRISTENSEN (1973), HARMANN \& PFLEGER (1974), NEERGAARD (1979) \& AGARWALL \& SINCLAIR (1987), como sendo os principais fungos de armazenamento em sementes de ervilha e de outras espécies.

\subsection{Doenças e Danos Causados por Microorganismos Associa- dos às Sementes de Ervilha}

Um grande número de patógenos ataca a cultura da ervilha, causando uma série de doenças, sendo que a maioria dos agentes causadores destas doenças săo transmitidos ou transportados pelas sementes. 
Segundo CAFE FILHO et alii (1989), mais de 20 generos de patógenos, principalmente fungos, foram associados à cultura da ervilha no Brasil.

SANTOS (1989) mencionou as seguintes doenças fúngicas transmitidas por sementes registradas no Brasil: ascoquitose, causada por Ascochyta pinodella, A. pinodes, $A$. pisi. e Ascochyta sp., antracnose - Colletotrichum pisi, murcha parcial - Fusarium oxysporium f. sp. pisi, fusariose - Fusarium solani f. sp. pisi, oidio - Oidium sp., mildio Peronospora pisi, podridao do colo - Rhizoctonia solani, mofo preto - Rhizopus sp., podridao de sclerotinia - Sclerotinia sclerotiorum e septoriose - Septoria pisi.

Além dos prëjuizos causados pelo estabelecimento de doenças na cultura da ervilha,os microorganismos transportados pelas sementes causam danos às estas e às plantulas. Com isto, os microorganismos tem sido apontados como um dos principais responsáveis pela reduçăo da qualidade das sementes CCHRISTENSEN, 1972; NEERGAARD, 1979; HALLOIN, 19863.

AGARWAL \& SINCLAIR (1987) mencionaram os vários prejuizos causados pelos microorganismos, como reduçăo na produtividade, perda da germinaçăo das sementes, desenvolvimento de doenças, enrugamento e ocorrencia de manchas nas sementes, deterioraçăo bioquímica e mudanças na qualidade nutricional das sementes e, por fim, produçăo de toxinas. Do acordo com CHRISTENSEN (1972), os fungos săo os principais agentes que atacam as sementes, sendo 
6.

divididos em fungos de campo e de armazenamento.

Os danos causados pelos fungos de campo ocorrem principalmente no campo, entretanto eles podem sobreviver por vários anos em sementes armazenadas com bai xos graus de umi dade e bai xas temperaturas (WETZEL,1987).

Segundo NEERGAARD (1979), os fungos de campo causam manchas nas sementes, reduzem a germinaça e causam doenças as plantulas ou plantas no campo. Durante o armazenamento das sementes, estes fungos necessitam al ta umidade relativa do ar, usualmente acima de $95 \%$ para se desenvolverem. Fungos de campo, como Fusarium, Alternaria, Helminthosporium e Cladosporium invadem as sementes durante a maturaça ou após a maturidade ejou durante a operaça de col heita (HALLOIN, 1986$)$.

As sementes atacadas por insetos ou microorganismos normalmente apresentam menor vigor. Esta incidencia e este efeito podem ter infcio no próprio campo, no perído de desenvolvimento e maturaçăo das sementes ou durante e ápos a colheita e o armazenamento, quando as condiç̧es são favoraveis ou quando nåo se realiza um controle dos microorganismos (CARVALHO \& NAKAGAWA, 1988 ).

LEACH \& SMITH (1945), mencionaram os fungos Rhizoctonia, Phytophthora, Fusarium e Botrytis como sendo os causadores de alta mortalidade de sementes e plantulas de ervilha.

O patógeno Ascochyta pisi, considerado um dos mais importantes na cultura da ervilha, provoca danos seve- 
ros no campo quaindo as plantas já se apresentam desenvolvidas, entretanto, năo causa problemas quanto à emergéncia em campo. BAYLIS (1941), demonstrou que Ascochyta pisi e Pleospora sp. tiveram pouco ou nenhum efeito na emergencia das plántulas. Resultado contrário foi encontrado por RICHARDSON (1979), o qual citou que Pleospora Sp, muito comum em sementes, provavelmente somente tem causado dano às plantulas.

Por outro lado, NEERGAARD (1979); mencionou que itycosphaerella pinodes causa podridão nas sementes durante a fase de. germinaçăo.

Quanto a Rhizoctonia solani, BITIENCOURT et alii (1985), relataram que um ataque severo deste patógeno poderá ocasionar reduçßes de até $38 \%$ da população inicial de plantulas de ervilha. Este fungo pode ainda se tornar um incómodo nos testes de laboratório, pois estes se espalham rapidamente nos germinadores causando tombamento nas plantulas durante os testes (NEERGAARD, 1979 ).

- fungo Botrytis cinerea quando infecta as sementes causa uma coloração branca, provocando ainda fal has na germi nação (RI CHARDSON, 1979). NEERGAARD (1979), cita que este fungo frequentemente reduz a germinaçăo das sementes, produzindo plantulas anormais.

Segundo Malone e Muskett, citados por NEERGAARD (1979), o fungo Cladosporium cladosporioides, comumente saprofita, causa morte às partes da planta e também às sementes. 
Os microorganismos, como Colletotrichum spp. e Ascochyta spp., comumente penetram através dos cotilédones, produzindo lesßes necróticas viśveis em sementes de feijăo, soja, ervilina, grăo de bico e outras leguminosas CNEERGAARD, 1979).

Além do dano direto às sementes, os microorganismos podem provocar depreciaçăo nos lotes, como é o caso de Cladosporium cladosporioides e Alternaria tenuis gue, ao infectarem as sementes, provocam manchas no tegumento, dando um aspecto indesejável nas mesmas (NEERGAARD, 1979). Causando perda na coloraçao de sementes de ervilha, o fungo Ascochyta pisi infecta o tegumento provocando visiveis necroses pretas, marrons e/ou cinzas (NEERGAARD, 1979 ).

RICHARDSON (1979), cita ainda que a bactéria Xanthomonas rubefaciens causa mancha púrpura em sementes de ervilha.

Os fungos de armazenamento, compreendem os generos Aspergillus e Penicillium, que podem estar presentes como contaminantes ou na forma de micelio dormente nas sementes e, em funçăo da temperatura e umidade relativa do ar podem se desenvolver e provocar danos às sementes armazenadas.

Decréscimos na germinaçăo, modificaçðes na cor e enrugamento nas sementes, aquecimento, deterioraçao do valor nutritivo e produçăo de toxinas săo apontados por AGARHAL \& SINCLAIR (1987), como sendo os principais danos destes microorganismos às sementes armazenadas. 
FIELDS \& KING (1962) armazenaram sementes de ervilha a $30^{\circ} \mathrm{C}$ e $85 \%$ de UR do ar, inoculadas com Aspergillus spp., e verificaram uma perda no poder germinativo aos seis meses nas sementes inoculadas, enquanto as sadias mantiveram a alta capacidade de germi naçăo.

Invasão de Aspergilius ruber, em sementes de ervilha, foi observada por HARMAKN \& NASH (1972) causando uma rápida perda na viabilidade destas. Ainda quanto a A. ruber, HARMAN (1972) inoculou sementes de ervilha com este patógeno e, após 14 semanas, observou uma maior anormalidade nas plântulas e um maior decréscimo na germinação das sementes.

Harmann et alii, citados por WETZEL (1987) sugeriram que a toxina produzida por Aspergillus ruber afeta a germinação em sementes de ervilha; causando injúrias às membranas, em especial das mitocóndrias.

Em trabalho com trigo, ervilha, abóbora e tomate, com diferentes isolados de Aspergilius, HARMAN \& PFLEGER (1974) observaram que sementes de ervilha foram infectadas por Aspergilius glaucus e Aspergilius restrictus, os quais causaram uma redução na germinaçăo das sementes. Verificaram ainda que estes fungos se localizavam no tegumento como também no ei xo embrionário.

TANAKA \& CORREA (1981) concluiram que Aspergillus e Penicillium podem causar a deterioraçăo de sementes de feijăo armazenadas em ambiente aberto. 


\subsection{Cultivares e Resistencia à Doenças}

Em trabalhos realizados por diversos pesquisádores foi verificado que a maior ou menor incidencia de determinados microorganismos nas sementes e plántulas ó influenciada pelos cultivares, quer seja pela composiçăo química das sementes, grau de permeabilidade das membranas ou composiçăo genica, a qual fornece alguma caracterfstica de resisténcia aos patógenos.

SHORT \& LACY (1974), comparando dois cultivares de ervilha, sendo um de sementes lisas e outro de sementes rugosas, observaram que cultivares de sementes rugosas exsudam maior quantidade de açúcarés durante o processo de germinaçăo e isto torna-os mais suscetiveis ao. ataque de microorganismos do solo.

Por outro lado, KRAFT (1974) testando alguns cultivares de ervilha quanto à resistencia de podridao de ralz causada por Fusarium e Pythium, observou que há uma variaçao destes cultivares na produçăo de fenóis, os guais reduzem o teor de açúcares nos exsudatos durante a germinaçăo das sementes; estes exsudatos interferem na esporulaçăo de Fusarium solani f. sp. pisi e Pythium ultimun.

Quanto à coloração das sementes, LORIA \& LACY (1979), citaram que sementes esmaecidas de ervilha de um mesmo cultivar sao mais suscetiveis ao tombamento, quando comparadas com sementes de coloraçăo normal. Os autores mencionaram ainda que sementes de ervilha no processo de 
germinação exsudam açúcares e aminoácidos que, ao se difundirem no solo, estimulam o crescimento de microorganismos, provocando a morte de sementes e plantulas.

Avaliando 100 genotipos de ervilha, CAFE FILHO et alii (1986) constataram em alguns, um certo nivel de resisténcia a Rhizoctonia solani, fungo este causador das podridßes de pré e pós emergéncia.

Sendo assim, cultivares mais suscetiveis ao ataque de microorganismos apresentam uma maior resposta ou necessitam ser tratadas com fungicidas para garantir um estabelecimento normal de plantulas em campo. WINDELS \& KOMMEDAHL (1982), mencionaram que cultivares de sementes rugosas, por possuirem um maior conteúdo de açúcares, quando comparadas com as cultivares de sementes lisas, se. beneficiam mais com o tratamento quimico ou biológico das sementes. Resultados semel hantes foram encontrados por KRAFT (1982) que observou que cultivares de sementes rugosas foram mais sensiveis a problemas causados por Pythium spp. e Rhizoctonia solani quando comparados com cultivares de sementes 1 isas.

A maior ou menor resposta ao tratamento qui mico em diferentes cultivares, pode tambem estar relacionada com a aderéncia do produto utilizado as sementes tratadas. Através de uma análise espectrofotométrica para detectar a aderéncia de Thiram em sementes de ervilha, MAUDE et alii (1986) encontraram diferenças significativas na aderéncia do produto entre os cultivares testados. 


\section{4. Fungicidas: Controle de Microorganismos}

$$
\text { Na impossibilidade de se utilizar sementes }
$$

livres de patógenos, o tratamento de sementes com produtos químicos pode oferecer proteção contra os microorganismos associados às sementes efou presentes no solo. Assim, segundo DHINGRA et alii (1980) o tratamento de sementes apresenta tres funçBes principais: proteger as sementes e as plantulas contra os patógenos causadores de apodrecimento e tombamento das plantulas; proteger as culturas contra as doenças causadas por patógenos das sementes e impedir o infcio de uma epidemia, tanto pela quantidade de inóculo inicial, como pelo número de "loci" de inóculo no campo; e, finalmente, proteger as sementes e as plantulas contra os patógenos, cujo "habitat" é o solo. Pode-se ainda incluir mais duas funçßes do tratamento químico das sementes como proteção dos fungos de armazenamento e patógenos da parte aérea nos primeiros estádios de crescimento (MACHADO, 1988 ).

Desta forma, inúmeros estudos tem sido realizados mostrando o efeito benéfico dos fungicidas na reduçăo dos patógenos nas sementes, bem como no controle das doenças no campo.

FORSBERG et alii (1944) verificaram o aumento do estande de ervilha em sementes tratadas com diferentes produtos fungicidas.

Irabal hando com sementes de ervilha infectadas com Mycosphaerella pinodes e Ascochyta pisi. MAUDE (1966) 
verificou que ambos os patógenos podem ser erradicados atraves da imersăo das sementes por 24 horas a $30^{\circ} \mathrm{C}$ em suspensZres de $0,2 \%$ de Captan ou Thiram. Ainda no controle de Ascochyta pisi, MAUDE \& KYLE (1970) eliminaram totalmente o patógeno das sementes de ervilha utilizando o tratamento de sementes com o fungicida Benomyl; citaram ainda que produtos a base de Carboxin, Captan e Thiram năo conseguem eliminar tal patógeno das sementes. Os fungicidas Benomyle Thiabendazole foram eficientes no controle de Ascochyta lentis em sementes da lentilha (KAISER \& HANNAN, 1987) e Ascochyta rabiei em sementes de grăo-de-bico CKAISER \& - HANNAN, 19883.

No controle de Pythium ulimum; o fungicida sistemico Metalaxil apresentou um melhor controle do patogeno, proporcionando assim uma melhor emergencia das plantulas em campo, quando comparados com as sementes não tratadas (LOCKE et alii, 1979). O autor mencionou ainda uma maior proteçăo deste fungicida em relaçăo aos produtos captan e Thiram. RICHARDSON (1973), observou um controle mais efetivo deste patógeno exercido pela mistura de Thiram + Chloroneb quando comparado com os produtos em separado.

Para o controle de Pleospora herbarum, RICHARDSON (1979) relatou que produtos mercuriais ou a base de Thiram são eficientes.

DHINGRA et alii (1980), citaram que o controle de Ascochyta pisi, Pythium ultimum, Rhizoctonia solani e Fusarium spp., em ervilha, pode ser feito atraves de trata- 
mento químico das sementes. Estes trés últimos patógenos citados foram controlados pelos fungicidas Captan e Thiram (KRAFT, 1982$).$

Trabalhando em condiçoses de Brasil Central, PITA et alii (1986) trataram sementes de ervilha com diferentes fungicidas, visando o controle de Rhizoctonia solani, e obtiveram incrementos significativos na emergéncia de plântulas com vários produtos testados.

Segundo O GRUPO PAULISTA DE FITOPATOLOGIA (1986), o produto Captan (Orthocide 750) na dosagem de $120 \mathrm{~g}$ de i.a/100 kg de sementes apresenta um controle para os patógenos Fusarium spp., Phytophthora spp., Pythium spp., Rhizoctonia solani e Sclerötinia sclerotiorum.

Quanto ao controle de Aspergilius spp. e Penicillium spP., NOVEMBRE (1987) citou vários trabalhos com tratamento fungicida em sementes de feijão, com uma melhor eficiencia dos produtos Benomyl, Captan e Thiram.

O fungicida sistêmico Benomyl tem sido citado exercendo uma maior eficiencia no controle de certos microorganismos associados às sementes CTHAPLIYAL \& SINCLAIR, 1970; ELLIS \& PASCHAL, 1979). Entretanto, alguns autores observaram que este fungicida nem sempre apresenta uma melhor resposta na emergéncia das plântulas em campo, quando comparado com outros produtos CELLIS \& PASCHAL, 1979; MINTON \& LEWIS, 19823.

Diante dos vários patógenos que causam dano à cultura da ervilha, existem atual mente no mercado diferentes 
15.

produtos químicos, alguns destes bastante eficientes no controle de tais microorganismos. Entretanto, segundo SANTOS (1989), citando uma lista de 23 ingredientes ativos de fungicidas promissores para a cultura, menciona que apenas os produtos Captan (Orthocide 750 ) e Quintozene (Pecenol 750 P) são registrados no Ministério da Agricultura para uso comercial no tratamento de sementes de ervilha.

\subsection{Fungicidas: Efeito na Qualidade das Sementes}

Os fungicidas, além do controle exercido nos microorganismos, podem também propiciar um efeito na qualidade fisiológica das sementes tratadas.

Verifica-se ainda, que poucos trabalhos foram conduzidos sobre o assunto com a cultura da ervilha; entretanto, na falta de bibliografia específica, foram abordados, nesta revisão, trabal hos com outras culturas, principalmente legumi nosas.

MARCOS FI.LHO \& PERRI JUNIOR (1977), trataram sementes de feijăo com Thiram e observaram um aumento na germinação e vigor das sementes: Resultados semelhantes também foram obtidos por MENTEN \& MENDES (1982), os quais verificaram a ocorréncia de uma maior porcentagem de germi nação em sementes de feijão tratadas com o mesmo produto.

Em trabalho com soja, MARCOS FILHO \& SOUZA

(1983) concluiram que o tratamento fungicida nas sementes antes do armazenamento pode beneficiar a conservação do vigor. 
16.

Efeitos de produtos fungicidas na qualidade fisiológica de sementes durante o armazenamento também foram estudados por VAN TOAI et alii (1986), os quais observaram que somente sementes de reduzida qualidade, isto é, sob prolongado período de armazenamento, responderam ao tratamento fungicida.

Diferentes respostas ao tratamento fungicida são obtidos em vários trabalhos. CARVALHO \& NAKAGAWA (1988), mencionam que a intensidade de resposta aos fungicidas varia de acordo com o nivel de vigor das sementes. Assim, sementes muito vigorosas ou com vigor muito baixo não reagem ao . tratamento fungicida; somente aquelas de vigor intermediário e que irão responder a este tratamento.

ELLIS et alii (1975) citaram que os fungicidas reduziram a quantidade de fungos associados às sementes e incrementaram a emergencia em sementes de soja de baixa qualidade Cgerminação abaixo de $70 \%$ e alta incidéncia. de microorganismos), enquanto que causaram pouco ou nenhum efeito em sementes de alta qualidade Cgerminação acima de $70 \%$ e baixa incidencia de microorganismos).

Trabalhando com sementes de feijão, ELLIS et alii (1976) observaram que sementes de baixa qualidade (germinação igual a $41 \%$ e com alta incidencia de fungos) se beneficiaram com o tratamento químico. Verificaram ainda que os produtos Captan, Thiram e Benomyl proporcionaram um aumento na germinação "in vitro", emergéncia em solo estéril - emergéncia em campo. 
Com tratamento fungicida em sementes de soja, BORELLI et alii (1978) mostraram que o mesmo provocou aumento na emergência total, na velocidade de emergéncia, no comprimento do epicótilo e no conteúdo de matéria seca das plantulas, qualquer que fosse o nivel de vigor das sementes utilizadas; entretanto, o tratamento de sementes foi mais eficiente quanto mais baixo fosse 0 nivel de vigor das sementes. Observaram, também, que as diferenças entre os nf veis de vigor considerados foram mais acentuadas para as sementes não tratadas do que para as tratadas.

Respostas distintas ao tratamento quimico em sementes de lotes de diferentes qualidade inicial também foram observados por MIRANDA \& SOUZA (1980), os quais verificaram um efeito benéfico maior do fungicida Thiabendazole em lotes de sementes de soja com baixo poder germinativo.

A utilização de sementes tratadas de soja, juntamente com uma maior profundidade de semeadura, é recomendável para manter a viabilidade e o potencial de emergéncia em solo com baixo teor de água e năo propenso à formaçăo de crosta na superficie (GILIOLI et alii, 1981 ).

PHIPPS (1984), mencionou que a utilizaçăo de fungicidas para tratamento de sementes de soja e amendoim incrementou a emergencia em campo, sendo citado a superioridade da mistura Benomyl + Thiram, aos tratamentos Benomyl e Thiram.

Segundo NOVEMBRE (1987), em trabalho com armazenamento de sementes de feijăo, os efeitos favoráveis 
dos fungicidas se manifestaram principalmente em lotes de baixa qualidade armazenados durante período prolongado.

Por outro lado, o efeito destes produtos ém algumas ocasibes pode ser negativos às sementes, causando redução na germinaçăo e aparecimento de plântulas anormais ou raquiticas (DHINGRA et alii, 1980 ).

Alguns trabalhos mencionam os efeitos fitotoxicos de fungicidas causando danos às sementes, como por exemplo em cevada (HAUAGGE \& SILVA,1980), em centeio e aveia (BALARDIN \& LOCH, 1987), em lentilha (MADEIRA et alii, 1988), e em grăo-de-bico (KAISER \& HANNAN, 1988 ).

BOLKAN et aiii (1976), trabalhando em condiçres de Brasil Central, vërificaram fitotoxicidade nas sementes de feijăo e soja tratadas com Acetato de Trifenil estanho.

Em sementes de ervilha, PFLEGER et alii (1976) observaram que os fungicidas Pyroxyclor e sulfato de cobre foram fitotóxicos para as duas cultivares testadas.

DHINGRA et ali $(1980)$, mencionaram que produtos a base de óxido de cobre ou óxido de zinco săo fitotóxicos para as sementes de ervilha e feijăo-de-Lima, enquanto Thiram, Ferbam e Cloranil săo benéficos para o tratamento de leguminosas, tais como ervilha e feijă. Estes autores citaram ainda que sementes com alto grau de umidade e apresentando danificaçชes mecanicas săo mais proplcias a fitotoxidez. O grau de fitotoxidez varia ainda de acordo com as especies, cultivares e coloraçăo das sementes. 
Interessante se faz comentar que tais efeitos fitotóxicos são mais acentuados efou mais visiveis nos testes de germinação em laboratório, onde geralmente o substrato utilizado (papel) permite uma concentraçăo maior do produto junto as sementes (C.ICERO et alii, 1989; SILVA, 1989).

\subsection{Armazenamento}

Face a defasagem das épocas de colheita e semeadura, o armazenamento constitui-se em uma etapa praticamente obrigatória em um programa de produçăo de sementes.

A umidade relativa do ar e a temperatura do ambiente de armazenamento "são os mais importantes fatores afetando a manutenção da qualidade das sementes durante o perfodo de armazenamento (DELOUCHE et alii, 1973). Destes dois fatores, sabe-se que a umidade relativa do ar é o mais importante, pois tem relaçăo direta com o grau de umidade das sementes.

Segundo ANDERSON \& BAKER (1983), a al ta umidade relativa do ar e o alto grau de umidade da semente aceleram a taxa de deterioraçăo das sementes, particularmente se a umidade destas for superior a $12 \%$

A completa perda na habilidade para germinar é a última consequência da deterioraçăo das sementes; entretanto, antes que isto aconteça, as sementes perdem progressivamente o vigor. Isto pode ser determinado pela maior sensibilidade as condiçơs de armazenamento, uma lenta e 
20.

desigual taxa de germinaçăo, uma menor emergencia de plantulas, um lento crescimento das plantas e um aumento no número de plantulas anormais (ANDERSON \& BAKER, 1983 ).

Sendo a ervilha uma cultura de inverno, o periodo compreendido eritre a colheita das sementes e a próxima semeadura, ou seja, o perfodo de armazenamento das sementes coincide, nas nossas condiçres tropicais, com periodos de altas temperaturas e alta umidade relativa do ar, condiç̧̄es estas extremamente adversas à manutenção da viabilidade das sementes.

ROBERTS \& ABDALLA (1968) testaram a qualidade - de sementes de ervilha com 12,3;15,4 e 18,0\% de umidade, armazenadas em tres ambientes com temperaturas de 25,35 e $40^{\circ} \mathrm{C}$ e verificaram uma reduça no período de viabilidade das. sementes a medida que se aumentava a temperatura e a umidade.

Trabalhando tamberm com diversas condiçoes de armazenamento, POHEL \& MATTHEWS (1977), observaram alteraços nas sementes, verificadas pelo teste de condutividade elétrica, sem contudo ter havido perda na viabilidade das sementes de ervilha armazenadas, tanto em condiçoes extremamente seca ( $1 \%$ de UR; $10^{\circ} \mathrm{C}$ ) e úmida (93\% de UR; $25^{\circ} \mathrm{C}$ ) após seis semanas. Em condiçðes intermediárias (45\% de UR; $\left.10^{\circ} \mathrm{C}\right)$ não foram observados alteraç̧es na qualidade das sementes. Verificaram ainda que a viabilidade das sementes reduziu apos seis semanas de armazenamento, em condiçðes de $93 \%$ de UR e $25^{\circ} \mathrm{C}$ e, após 2 dias em condiçzes de $94 \%$ de UR a $45^{\circ} \mathrm{C}$. As sementes mantiveram a sua viabilidade tanto em condiçơs 
21.

de bai xa umidade como em condiçßes intermediárias.

Além dos efeitos diretos da umidade relativa do ar (ou grau de umidade da semente) e da temperatura do ambiente de armazenamento sobre a conservação das sementes, diversos trabalhos enfatizaram os efeitos indiretos desses fatores, sobre a ação de microorganismos responsáveis pela deterioração das sementes armazenádas.

Segundo CHRISTENSEN (1972), os fungos de campo não se desenvolvem em sementes armazenadas, desde que estas apresentem um teor de água adequado para o armazenamento, pois estes microorganismos perdem gradualmente a viabilidade. A maioria dos fungos de campo são senslveis a altas temperaturas e usualmente desaparecem em tais condiçres. Entretanto Aiternaria teruis pode se desenvolver a temperatura acima de $40^{\circ} \mathrm{C}$ (NEERGAARD, 1979 ).

Os fungos de armazenamento, principalmente Aspergilius e Penicillium, são adaptados a ambiente com baixa umidade, podendo se desenvol ver em materiais cujos conteúdos de umidade estejam em equilibrio com umidade relativa do ar de 65 a $90 \%$ ( WETZEL, 1987 ).

Espécies de Penicillium usualmente são encontrados em lotes de sementes armazenados a baixa temperatura e com grau de umidade das sementes acima de 16\%. Em geral, as espécies de Penicillium se desenvolvem em sementes com. teor de água maior quando comparados com as espécies de Aspergil zus (WETZEL, 1987 ). 
Quanto a temperatura, os fungos de armazenament.o em geral crescem mais rapidamente a 30 e $32^{\circ} \mathrm{C}$. Entretanto, algumas raças de Aspergillus glaucus crescem lent.amente próximas de $0^{\circ} \mathrm{C}$ e certas espécies de Penicillium podem crescer a temperaturas abaixo de zero. Em geral, estes fungos tem, para o seu máximo desenvolvimento, uma temperatura stima de 30 a $40^{\circ} \mathrm{C}$.

Pelo exame de literatura, pode-se verificar que existem variaçós nas respostas ao uso de fungicidas em função do produto e dosagem ut.ilizados, dos genótipos, do nivel de qualidade das sementes e dos microorganismos a elas associados. Portanto, estudos neste sentido devem ser conduzidos com o objetivo de se encontrar produtos mais eficientes no controle de determinados microorganismos que, por seus efeitos diretos ou indiretos, possam contribuir para a qualidade das sementes de ervilha. 
23.

\section{MATERIAL E METODOS}

O presente trabalho foi conduzido no Laboratorio de Analise de Sementes do Departamento de Agricultura (LAS/LAG) e no Laboratório de Patologia de Sementes do Departamento de Fitopatologia (LPS/LFT), ambos da Escola Superior de Agricultura "Luiz de Queiroz", da Universidade de São Paulo (ESALQ/USP), em Piracicaba, Estado de São Pau10. Os ensaios de campo foram realizados no Campo Experimental do Centro Nacional de Pesquisa de Hortalicas/EMBRAPA, em Brasilia, Distrito Federal. O. periodo experimental teve infcio em outubro de 1988, estenderido-se até jul ho de 1989.

\subsection{Sementes e Cultivares}

Para a realização da pesquisa, foram utilizadas sementes de ervilha, safra 1988, sendo dois lotes do Cultivar Mikado (sementes lisas), produzidas pelo Servico de Produção de Sementes Básicas/EMBRAPA; e dois lotes do cultivar Pomak (sementes rugosas), produzidas pela Asgrow do Brasil Sementes Ltda.

Após a recep̧ão, em outubro de 1988, os lotes for am homogeneisados, utilizando-se um divisor cónico. 
24.

\subsection{Tratamentos Fungicidas}

Após a recepção e homogeneizaçăo, cada um dós lotes foi dividido em onze amostras de $2,0 \mathrm{~kg}$, constituindo os tratamentos discriminados na Tabela 1.

Tabela 1 - Tratamentos, nome técnico, nome comercial e dosagem dos produtos utilizados na pesquisa.

\begin{tabular}{|c|c|c|c|c|}
\hline TRATAMENTOS & $\begin{array}{l}\text { NOME } \\
\text { TECCNICO }\end{array}$ & $\begin{array}{c}\text { NOME } \\
\text { COMERCIAL }\end{array}$ & $\lg \frac{d \theta}{d \theta}$ & $\begin{array}{l}\text { DOSAGENS } \\
\text { i. a/100 kg } \\
\text { sementess }\end{array}$ \\
\hline Testemunha & - & - & & - \\
\hline Captan (125) & Captan & Captan 50 & & 125 \\
\hline Captan (250) & Captan & Captan $50^{\circ}$ & & 250 \\
\hline Thiram (140) & Thiram & Rhodiauram & 70 & 140 \\
\hline Thiram (280) & Thiram & Rhodiauram & 70 & 280 \\
\hline Iprodione (100) & Iprodione & Rovral so & & 100 \\
\hline Iprodione (200) & Iprodione & Rovral 50 & & 200 \\
\hline Benomyl (100) & Benomyl & Benlateso & & 100 \\
\hline Benomyl (z00) & Benomyl & Benlale 50 & & 200 \\
\hline Iprod. (50)+Thir. (150) & Iprodione+thiram & Rovrim & & 200 \\
\hline Iprod. (100)+Thir. (300) & Iprodione+thiram & Rovrim & & 400 \\
\hline
\end{tabular}

A escolha das dosagens utilizadas dos produtos nåo registrados para a espécie, foi feita com base na recomendaçao para o tratamento de sementes das grandes culturas; a dosagem menor foi aquela pescrita no rótulo do produto, a maior, o dobro desta.

Para a aplicaçăo dos fungicidas procedeu-se da seguinte maneira: as sementes foram espalhadas sobre uma 
lona plástica; cóm auxilio de um pulverizador do tipo toalete, as sementes foram levemente umedecidas para depois terem a quantidade correspondente do produto espalhada sobre as mesmas e misturadas de tal modo que o fungicida cobrisse as sementes de maneira mais uniforme possivel. Após isto, as sementes foram secadas à sombra por 24 horas. Cada amostra foi dividida manualmente em quatro partes iguais, com aproximadamente 500 gramas cada, constituindo-se assim as repetiç̧es.

\section{3. Armazenamento}

As sementes foram acondicionadas em sacos de papel "kraft" e permaneceram armazenadas em condiçסes de ambiente do LAS/LAG/ESALQUUSP durante o perlodo de novembro de 1988 a abril de 1989. Os dados referentes a temperatura e umidade relativa do ar foram registrados diariamente, atraves de termohigrógrafo; os dados obtidos encontram-se na Tabela 2 .

\section{4. Avaliaçáo da Qualidade das Sementes}

As avaliaçסes foram realizadas em trés épocas (intervalos trimestrais), sendo a primeira logo após o tratamento fungicida $\cos$, a segunda aos tres meses de armazenamento ( 3 ) a terceira época aos seis meses, no final do período de armazenamento (6). 
26.

Tabela 2 - Temperatura (média, máxima e minima) e umidade relativa do ar, média dos decendios, durante o armazenamento dos lotes de sementes de ervilhas cvs. Mikado e Pomak. Piracicaba, 1988/1989.

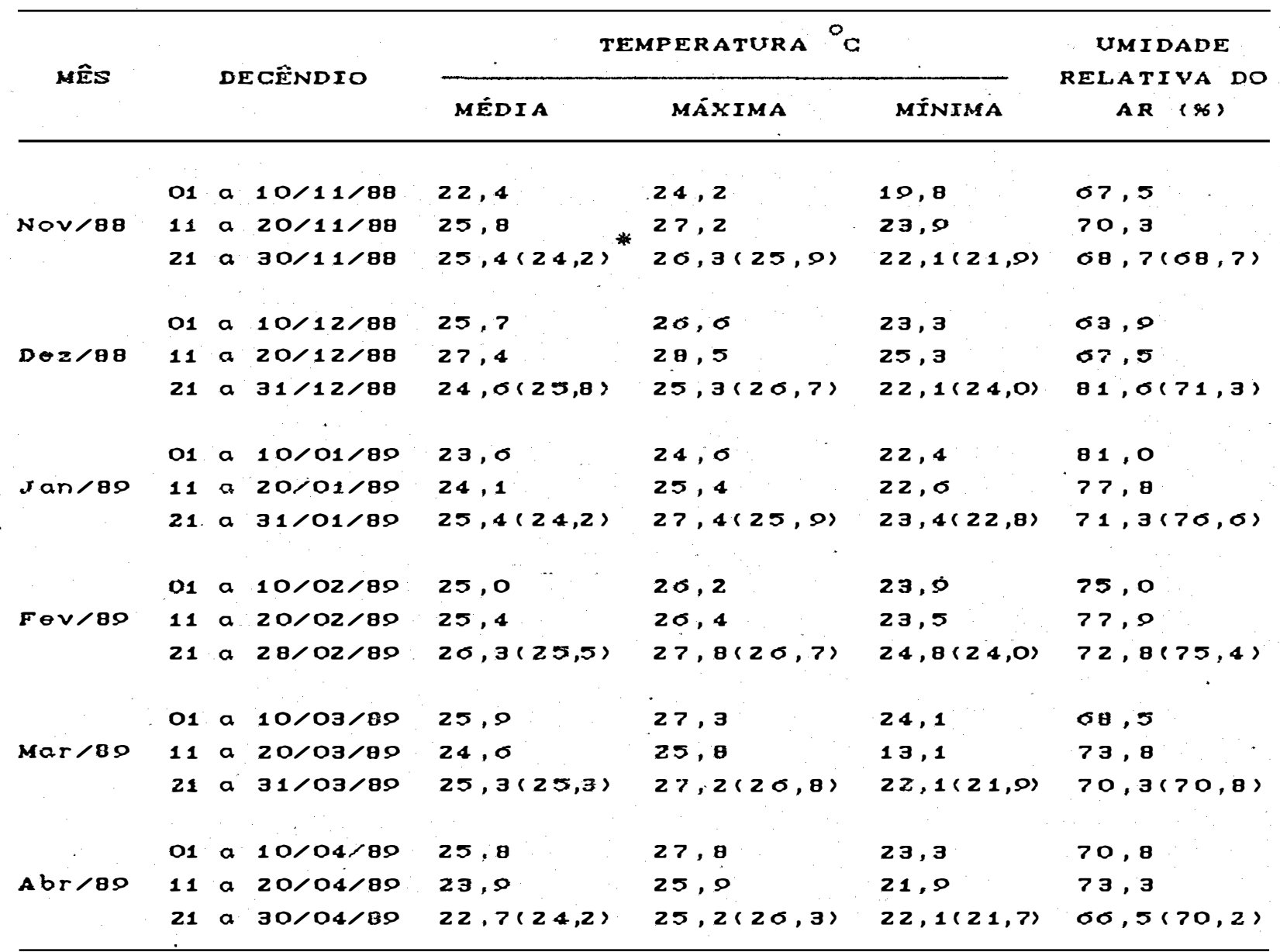

Médias mensais entro parênteses.

\subsubsection{Germinaçao}

Realizado com 200 sementes 44 repetiçßes de 50 sementess para cada tratamento, semeadas em rolo de papel toalha "Germitest" e colocadas para germinar em aparelho Stults, sob temperatura constante de $20^{\circ} \mathrm{C}$. 0 volume de água utilizado para a embebiç̃o foi equivalente a 2,5 vezes o 
peso do substratio. As contagens foram realizadas aos 5 e 8 dias após a semeadura e, as avaliaçôs, efetuadas segundo os critérios estabelecidos pelas Regras para Análise de Sementes (BRASIL, 1980); computaram-se as porcentagens de plantulas normais para cada repetiçăo, obtendo-se dados médios por repetição.

\subsubsection{Primeira contagem de germinaço}

Foi conduzido conjuntamente com o teste de germinaçăo, sendo a leitura realizada no guinto dia após a instalação do mesmo, conforme descrição contida em MARCos FILHO et ai i (1987).

\section{4. 3. Envel hecimento acelerado}

Utilizaram-se 200 sementes por tratamento, em 4 repetiçoes de 50 sementes, distribuidas sobre uma bandeja de tela de aluminio fixada no interior de uma caixa plástica tipo "Gerbox", funcionando como compartimento individual (mini-cámara). No interior dessa mini-cámara foram adicionados $40 \mathrm{ml}$ de água e, em seguida, os "Gerbox" adaptados for am levados a uma incubadora, conforme metodologia recomendada pelo Comite de Vigor da "ASSOCIATION OF OFFICIAL SEED. ANALYSTS" (1983) e descrita por MARCOS FILHO et ai i i (1987). As sementes permaneceram em incubadora, marca Fanem, regulada a temperatura constante de $42^{\circ} \mathrm{C}$ durantie 48 horas. Após 
28.

este periodo, as sementes foram colocadas para germinar, conforme descrito no item 3.4.1.

A avaliaçăo das plantulas foi realizada cinco dias após a semeadura, computando-se a porcentagem de plantulas normais por amostra e obtendo-se dados médios para cada repetição.

\subsection{Condutividade elétrica}

Conforme metodologia recomendada pelo comite de Vigor da "ASSOCIATION OF OFFICIAL SEED ANALYSTS" (1983), utilizaram-se quatro repetiçres de 25 sementes para cada tratamento, escolhidas para remoçăo daquelas com tegumento danificado mecanicamente e pesadas em balança com preciså de $0,01 \mathrm{~g}$. Em seguida, as sementes foram colocadas em copos plásticos contendo $75,0 \mathrm{ml}$ de água destilada, permanecendo em germinador, marca Burrows, a temperatura constante de $20^{\circ} \mathrm{C}$ durante 24 horas. Decorrido este periodo, a condutividade elétrica da soluçăo foi determinada através de condutivímetro, marca Digimed, sendo os valores médios obtidos para cada repetição expressos em umhos por grama de sementes.

\section{4.5. Emergencia das plantulas em campo}

Foram utilizadas quatro repetiçßes de 50 sementes por tratamento, distribuidas a uma profundidade de $0,05 \mathrm{~m}$ em sulcos de $2,0 \mathrm{~m}$ de comprimento, no espaçamento de 
29.

$0,20 \times 0,04 \mathrm{~m}$. For am realizadas irrigaçöes periódicas, sempre que necessário. As contagens foram efetuadas aos 15 dias após a semeadura, computando-se as porcentagens de plantulás emersas. As datas de semeadura for am $17 / 12 / 88,10 / 03 / 89$ e 25/06/89. Os dados de temperatura e precipitação pluvial referentes a essas épocas encontram-se nas Tabelas 3,4 e 5 .

Tabela 3 - Temperatura (média, máxima e minima) e precipitacão pluvial diárias, durante a primeira época de semeadura dos lotes dos cvs. Mikado e Pomak. Brasilia, $1988 / 1989$.

\begin{tabular}{|c|c|c|c|c|}
\hline \multirow{2}{*}{ DATA } & \multicolumn{3}{|c|}{ TEMPERATURA } & PRECIPITAÇÃO \\
\hline & MÉDIA & $M A X I M A$ & $M$ INIMA & - $\quad$ monsal. $\rangle$ \\
\hline $12 / 12$ & 21,5 & 25,8 & 18,4 & 47,3 \\
\hline $13 / 12$ & 20,0 & 23,0 & 10,0 & 20,0 \\
\hline $14 / 12$ & 22,6 & 26,4 & 10,4 & 0,0 \\
\hline $15 / 12$ & 21,1 & 25,8 & 17,0 & 50,0 \\
\hline $16 / 12 *$ & 21,5 & 25,6 & 16,2 & 50,2 \\
\hline $17 / 12^{*}$ & 22,1 & 27,8 & 10,8 & 17,5 \\
\hline $18 / 12$ & 22,3 & 26,8 & 16,0 & 8,5 \\
\hline $10 / 12$ & 22,5 & 26,2 & 18,0 & $\mathbf{3}, \mathbf{0}$ \\
\hline $20 / 12$ & 22,5 & 27,8 & 17,5 & 9,6 \\
\hline $21 / 12$ & 23,0 & 28,6 & 20,5 & $\mathbf{0}, \mathbf{0}$ \\
\hline $22 / 12$ & 22,4 & 20,8 & 18,0 & 0,0 \\
\hline $23 / 12$ & 20,8 & 27,0 & 18,0 & 12,5 \\
\hline $24 / 12$ & 20,1 & 27,8 & 18,8 & 0,3 \\
\hline $25 / 12$ & 20,6 & 20,0 & 17,5 & 3,6 \\
\hline $20 / 12$ & 22,8 & 28.2 & 17,5 & 0,3 \\
\hline $27 / 12$ & 25,5 & 30,0 & 16,0 & 0,0 \\
\hline 28,12 & 25,1 & 30,0 & 15,6 & 0,0 \\
\hline $20 / 12$ & 25,5 & 30,8 & 17,5 & 0,0 \\
\hline $30 / 12$ & 27,4 & 32,8 & 18,0 & 0,0 \\
\hline $31 / 12$ & 25,0 & 30,0 & 17,2 & 4,5 \\
\hline $01 / 01$ & 22,1 & 28,0 & 10,0 & 0,0 \\
\hline
\end{tabular}

Data de semeadura;

**

Data de contagem. 
Tabela 4 - Temperatura (média, máxima e minima) e precipitaçăo pluvial díarias, durante a segunda época de semeadura dos lotes dos crs. Mikado e Pomak. Brasilia, 1989.

\begin{tabular}{|c|c|c|c|c|}
\hline \multirow{2}{*}{ DATA } & \multicolumn{3}{|c|}{ TEMPERATURA ${ }^{\circ} \mathrm{C}$} & \multirow{2}{*}{$\begin{array}{r}\text { PRECIPITACÃO } \\
(\mathrm{mm} / \mathrm{all} \mathrm{l})\end{array}$} \\
\hline & MEDDA & $M A ́ X I M A$ & MINIMA & \\
\hline $05 / 03$ & 25,0 & 30,4 & 10,5 & 0,0 \\
\hline $00 / 03$ & 24,0 & 30,0 & 10,5 & 0,0 \\
\hline $07 / 03$ & 24,0 & 20,8 & 17,8 & 0,0 \\
\hline $08 / 03$ & 23,7 & 20,2 & 16,2 & $0 ; 0$ \\
\hline $00 / 03_{*}$ & 24,0 & 20.0 & 10,8 & 0,0 \\
\hline $10 / 03^{*}$ & 25,3 & 20,4 & 18,0 & 0,0 \\
\hline $11 / 03$ & 24,1 & 20,8 & 18,0 & $0 ; 0$ \\
\hline $12 / 03$ & 22,0 & 20,2 & 18,5 & 4,2 \\
\hline $13 / 03$ & 22,2 & 28,0 & 18,5 & $30 ; 4$ \\
\hline $14 / 03$ & 22,0 & 28,0 & 18,2 & 20,7 \\
\hline $15 / 03$ & $2 \mathbf{3}, 0$ & $28, \sigma$ & 10,0 & 0,1 \\
\hline $10 / 03$ & 24,6 & $28, \mathrm{~B}$ & 17,4 & 0,0 \\
\hline $17 / 03$ & 24,1 & 20,0 & 18,0 & 0,0 \\
\hline $18 / 03$ & 23,5 & 20,0 & 10,8 & 0,0 \\
\hline $10 / 03$ & 24,2 & 20,8 & 18,0 & 0,0 \\
\hline $20 / 03$ & 21,0 & 28,2 & $17,=$ & $0, c$ \\
\hline $21 / 03$ & 20,5 & 27,4 & 18,2 & 2,4 \\
\hline $22 / 03$ & 23,2 & 20,0 & 15,4 & 1,8 \\
\hline $23 / 03$ & 21,8 & 28,6 & 18,0 & 0,0 \\
\hline $24 / 03^{* *}$ & 23,4 & 27,0 & $18 ; 4$ & 0,0 \\
\hline $25 / 03^{*}$ & 23,0 & 27,8 & 17,5 & $\mathbf{0}, \mathbf{0}$ \\
\hline
\end{tabular}

* Data de semeadura;

* Dara de contagem. 
Tabela 5 - Temperatura (média, máxima e mínima e precipitaçăo pluvial diárias, durante a terceira época de semeadura dos lotes dos evs. Mikado e Pomak. Brasilia, 1989.

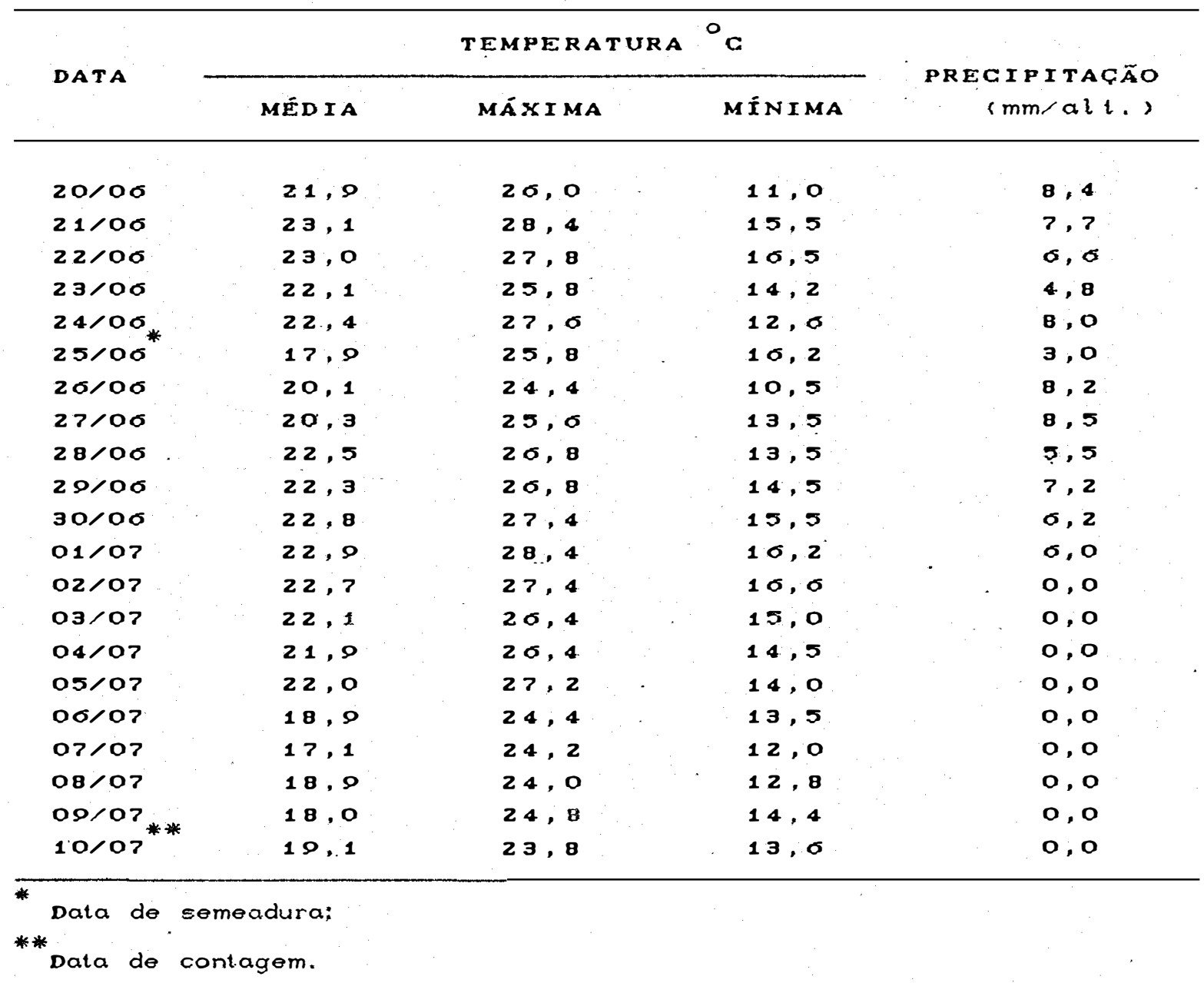

3. 4. 6. Determinaçăo do grau de umidade

Foi efetuada pelo método da estufa, a $105 \pm$ $3^{\circ} \mathrm{C}$, durante 24 horas, utilizando-se duas sub amostras por repetiçăo, conforme as prescriçßes das Regras para Análise de Sementes (BRASIL, 1980). Os resultados foram expressos em porcentagem média para cada repetiçăo. 


\section{4. 7. Sanidade das sementes}

Foram utilizadas quatro repetiçóes de 50 sementes por tratamento. Utilizou-se o método do papel de filtro com congelamento, conforme descrito por NEERGAARD (1979). As sementes foram distribuldas em placas de Petri plástica, contendo trés folhas de papel de filtro, previamente umedecidas em água destilada, sendo colocadas 10 sementes por placa. Em seguida, estas foram colocadas em câmara para incubação, a temperatura constante de $20^{\circ} \mathrm{C} \mathrm{em}$ regime de 12 horas com 1 uz branca fluorescente al ternada por 12 horas de escuro. A seguir estas foram colocadas em um "freezer", à temperatura de $-20^{\circ} \mathrm{C}$, durante 24 horas, com a finalidade de se evitar a germinação das sementes; em seguida, retornaram à cámara de incubaçăo por cinco dias, completando o período de 7 dias para a avaliação da porcentagem de microorganismos presentes nas sementes. A porcentagem e identidade dos microorganismos encontrados foram avaliados com o auxilio de microscópio estereoscópio Caumento de 40 a 60 vezes); quando necessária a identificação das estruturas dos microorganismos foi feita utilizando-se microscópio composto (aumento de 100 a 400 vezes).

\subsection{Procedimento Estatistico}

Os dados obtidos nos testes de germinaçăo, primeira contagem de germinaçă, envel hecimento acelerado,e 
33.

emergéncia das plántulas em campo foram transformados em arc sen $\sqrt{\text { Porcentagem } / 100}$, enquanto os referentes à condutividade elétrica não foram transformados.

Os dados referentes a determinação do grau de umidade das sementes, bem como a análise de sanidade, não foram analisados estatisticamente.

A análise de variáncia foi realizada separadamente para cada cultivar e época. O delineamento utilizado foi o inteiramente casualizado, em arranjo fatorial com quatro repetiçäes. para os testes de laboratório, enquanto que para emergência das plantulas em campo foi utilizado o delineamento em blocos casualizados. Os esquemas utilizados para a análise de variancia se encontram nas Tabelas 6 e 7.

Tabela 6. - Esquema da análise de variáncia para cada cultivar, com os dados obtidos nos testes de laboratório.

\begin{tabular}{|c|c|c|}
\hline causas de variacão & ORAUS & DE LIBERDADE \\
\hline Loles & . & 1 \\
\hline Tralamentos & & 10 \\
\hline Lolos x Tralamentos & & 10 \\
\hline Residuo & & 00 \\
\hline$A L$ & & 87 \\
\hline
\end{tabular}


Tabela 7 - Esquema da análise de variancia para cada cultivar, com os dados obtidos nos testes de campo.

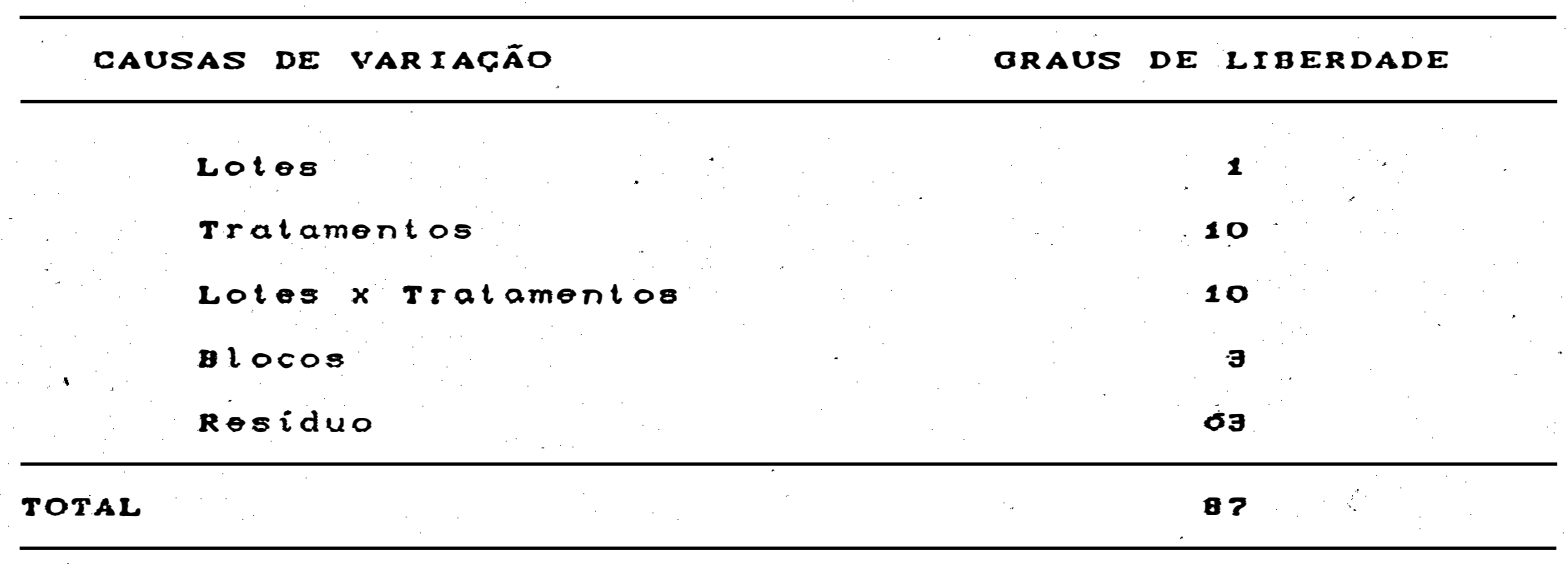

Nos casos em que a interaçăo Lotes $x$ Tratamentos foi significativa, foi realizado o desdobramento dos graus de liberdade para verificar os efeitos dé lotes dentro dos tratamentos e de tratamentos dentro de lotes.

A comparação entre as médias foi efetuada atraves do teste de Tukey, ao nivel de 5\% de probabilidade. 
35.

\section{RESUltados E DISCUSSAO}

\subsection{Cultivar Mikado}

Os valores de F para efeito de tratamentos nos testes realizados nas respectivas épocas de análise encontram-se na Tabela 8.

\subsubsection{Germinaçao}

Conforme se observa na Tabela 8 , a interação Lotes $x$ Tratamentos não foi significativa para este paråmetro. Com isto, a discussão foi feita com base na média dos dois lotes (Tabela 9).

No inf́cio do armazenamento, à exceção do tratamento com Iprodione $(100 \mathrm{~g}$ de i.a/100 $\mathrm{kg}$ desementes), todos os demais proporcionaram um pequeno aumento da porcentagem de germinação quando comparadas com sementes não tratadas, embora sem significado estatistico. Nesta primeira época, a incidéncia da maioria dos microorganismos associados as sementes foi maior, (Tabelas 15 \& 16), quando comparadas às duas outras épocas; e pode-se, então, verificar umà maior resposta aos produtos fungicidas pelas sementes, proporcinando assim um efeito benéfico à germinaçăo. 
36.

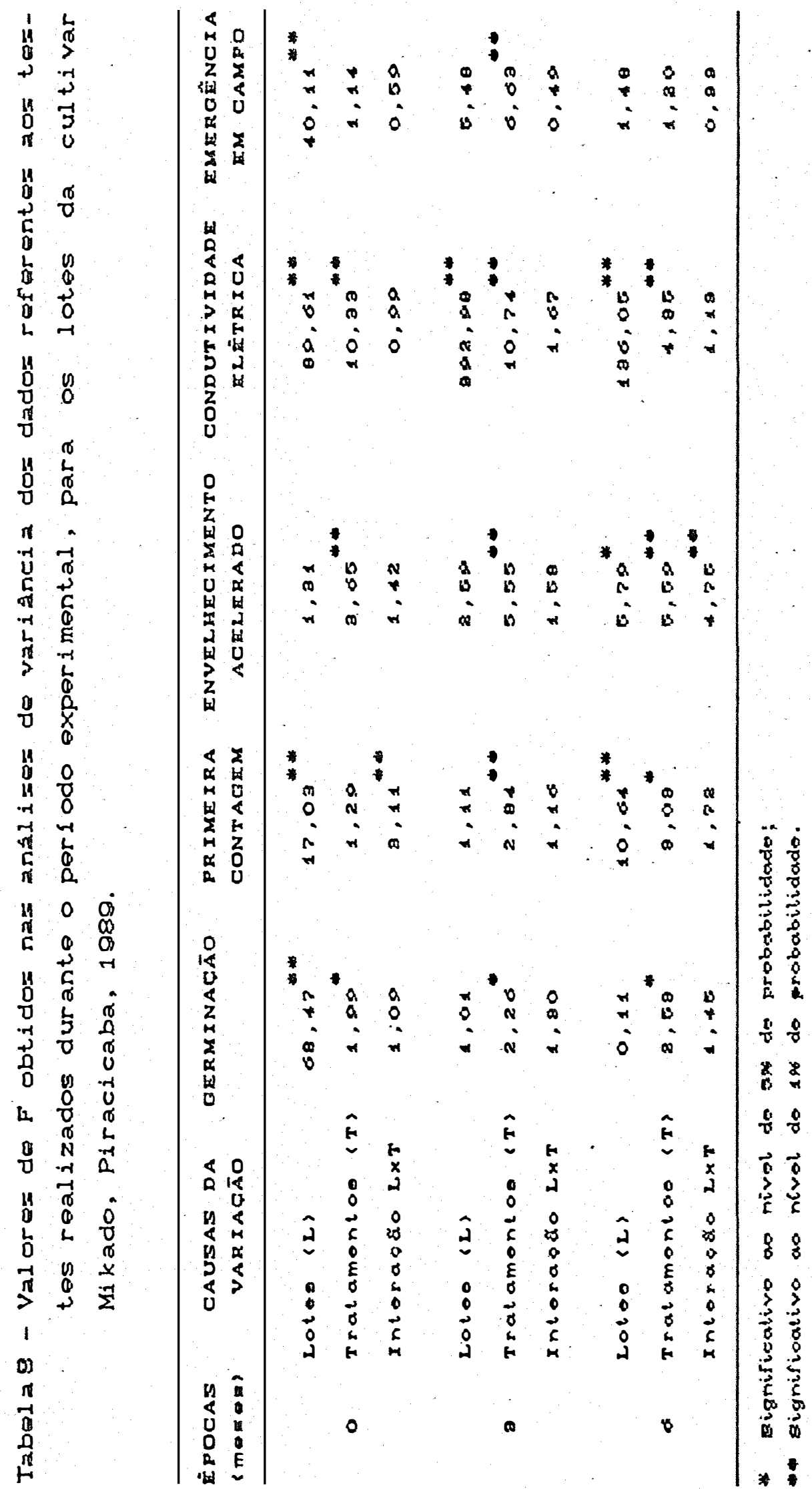




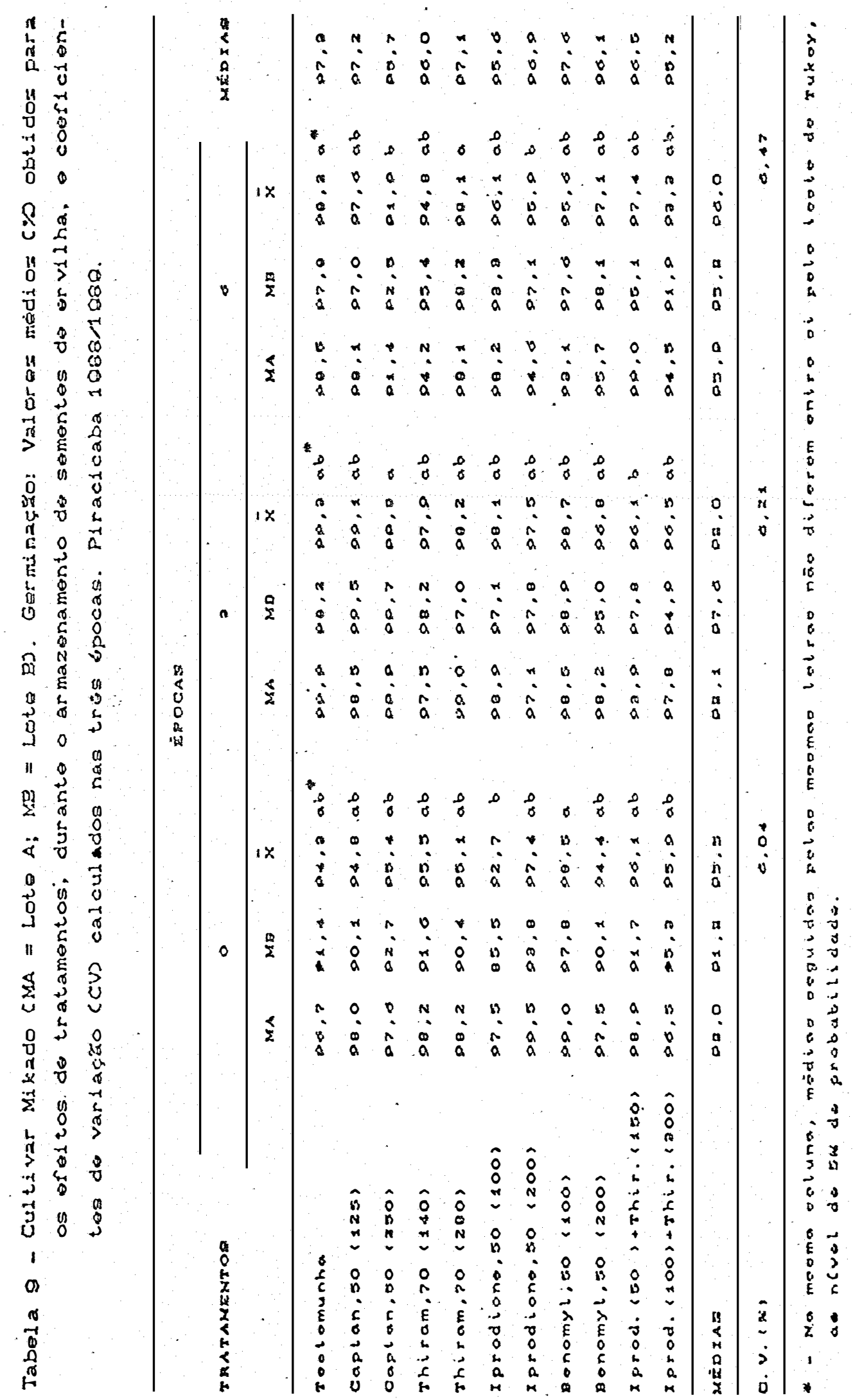

37. 
38.

Após trés meses de armazenamento, também não se observou diferença significativa entre a testemunha e os tratamentos fungicidas. Com exceça do tratamento laptan (250 $\mathrm{g}$ de $i . a / 100 \mathrm{~kg}$ de sementes), todos os demais foram numericamente inferiores à testemunha.

No final do período de armazenamento, aos seis meses, verificou-se que todos os tratamentos com fungicidas apresentaram uma menor porcentagem de germinaçăo quando comparado às sementes năo tratadas. Observou-se ainda uma diferença significativa entre as médias da testemunha e os produtos Captan (250 $\mathrm{g}$ de i.a/100 $\mathrm{kg}$ de sementes) e Iprodione (200 $\mathrm{g}$ de $\mathrm{i} . \mathrm{a} / 100 \mathrm{~kg}$ de sementes) permitindo assim verificar um efeito fitotóxico mais acentuado deste produto na dosagem citada. SILVA (1989), trabalhando com milho, mencionou que o tratamento fungicida pode reduzir o número de plantulas normais e elevar o número de plantulas anormais em virtude da dosagem recomendada do produto considera o solo como substrato de germinaçăo e que, quando utilizado o papel (teste de germinaçăo), o problema se agrava. Cif CERO et alii (1989), citam também que as particulas do solo absorvem - produto em maior quantidade e, no substrato papel, a concentraçăo dos fungicidas junto as sementies $\&$ maior, podendo com isto causar um efeito fitotóxico.

Efeito fitotóxico, causado por alguns produtos fungicidas aplicados às sementes de lentilha, verificado no teste de germinaçăo, também foram observados por MADEIRA et alii (1988). Os autores observaram, ainda, que grande parte 
39.

dos tratamentos incrementaram a germinaçăo aos 90 dias de armazenamento; quando testados aos 150 dias, a maioria dos tratamentos fungicidas provocou uma reduçăo na germinaçăo. DHINGRA et alii (1980) citaram que os danos às sementes, causados pelos fungicidas, podem aumentar com o decorrer do período de armazenamento.

Como se pode veriricar nas tres epocas estudadas, nåo se obteve uma resposta considerável na germinaçăo quando se utilizaram sementes tratadas; isto pode estar relacionado com a alta qualidade fisiológica destas sementes no infcio do armazenamento, o que segundo CARVALHO \& NAKAGAWA (1988), sementes com al to vigor nå reagem ao tratamento com fungicidas.

\subsubsection{Primeira contagem de germinaça}

Para este parámetro verificou-se uma interaçåo Lotes $x$ Tratamentos apenas na primeira época estudada; assim, a discussăo foi realizada separadamente para os dois lotes apenas nesta época (Tabela 10 ). 
40.

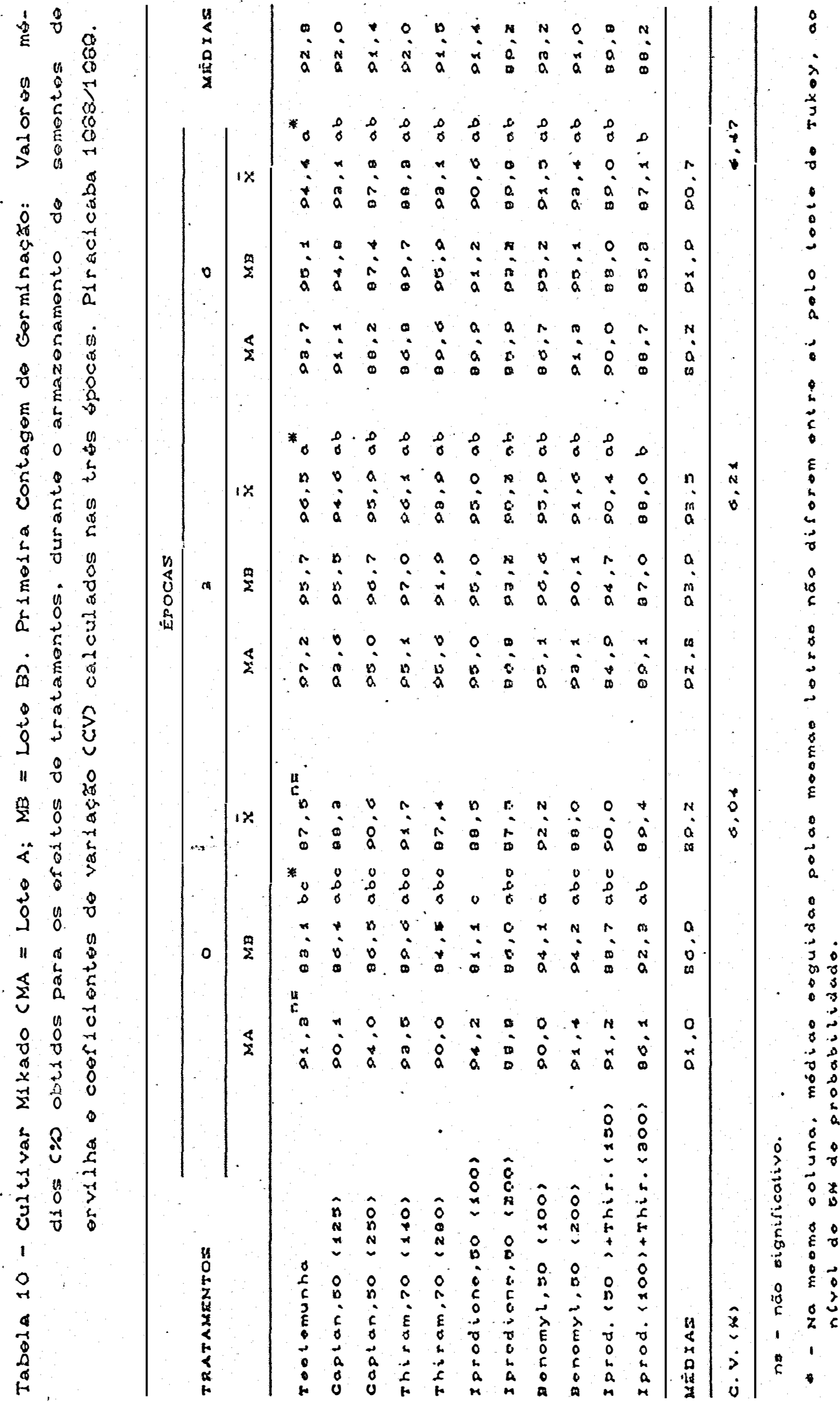


Para o lote MA não foi observada diferença significativa entre os tratamentos no infcio do armazenamento. Com relação ao lote $M B$ a análise de variáncia revelou diferenças significativas entre alguns produtos fungicidas, e também uma superioridade do fungicida Benomyl c100 g de i. a $/ 100 \mathrm{~kg}$ de sementes) em relação à testemunha. Na média dos dois lotes, a maioria dos fungicidas proporcionou um maior valor de germinação aos cinco dias, quando comparadas com a testemunha, embora não houvesse diferenças significativas.

Como no teste de germinação, verificou-se uma pequena redução da germinação na primeira contagem nas sementes tratadas, quando comparados com as sementes não tratadas, tanto aos trés como aos seis meses de armazenamento. Nestas duas épocas, a análise de variância revelou diferença significativa apenas entre a testemunha e o tratamento Iprodione + Thiram na dosagem maior. MADEIRA et alii (1988) também verificaram uma fitotoxidez da mistura Iprodione + Thiram quando se utilizou a mesma dosagem em sementes de lentilha, reduzindo assim a germinação e o peso da matéria seca das plantulas; observaram ainda uma tendencia de redução na porcentagem de germinação das sementes quando se utilizaram dosagens mais elevadas para a maioria dos produtos em estudo. 
4.1.3. Envelhecimento acelerado

Na Tabela 11 se encontram os dados referentes ao teste de envelhecimento acelerado. Em todas as épocas estudadas observaram-se diferenças significativas entre os tratamentos; pode-se verificar também uma resposta crescente para alguns produtos fungicidas a medida em que o tempo de armazenamento evoluiu. Estes resul tados também for am constatados por MARCOS FILHO \& SOUZA (1983) e NOVEMBRE (1987) em sementes de soja e feijão, respectivamente.

No inficio do armazenamento, as sementes tratadas com Captan (125 g de i.a/100 kg de sementes), e com a mistura Iprodione + Thiram" $50+150 \mathrm{~g}$ de i.a/100 kg de sementes) apresentaram valores numéricos superiores aos demais tratamentos. Estes dois tratamentos diferiram estatisticamente apenas do tratamento com Iprodione, nas duas dosagens. Aliás, o produto Iprodione foi o que apresentou o menor valor numérico de vigor, quando comparado aos demais tratamentos.

Aos trés meses de armazenamento, observou-se diferença significativa entre os tratamentos, sendo que o tratamento com Iprodione + Thiram $150+150 \mathrm{~g}$ de i.a/100 kg de sementes), apresentou um maior valor numérico; somente este tratamento diferiu estatisticamente da testemunha. Nesta mesma época, verificourse ainda um menor valor numérico do vigor das sementes tratadas com esta mistura quando em dosagem mais el evada. 
43.

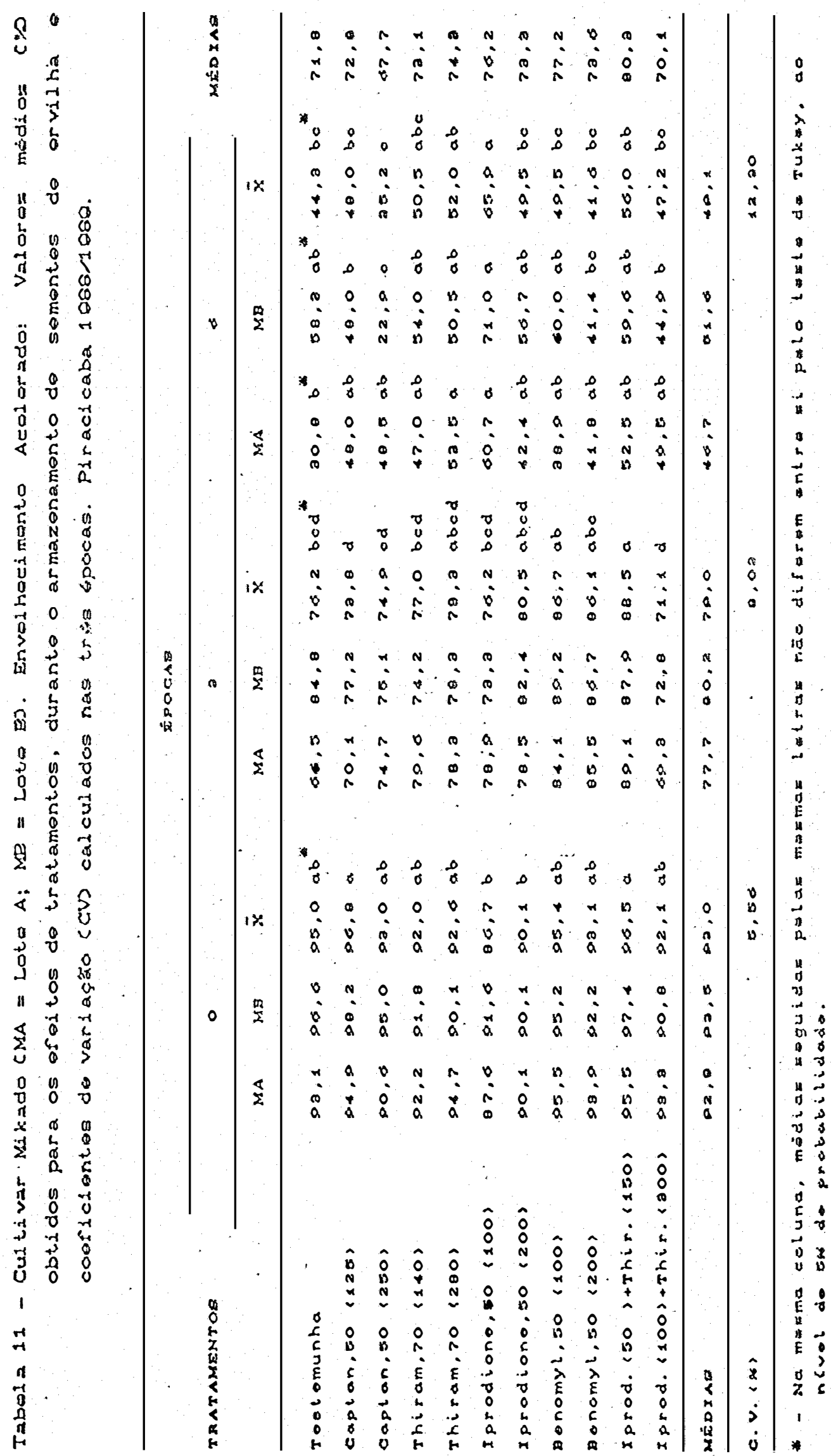


Ja aos seis meses, houve interaçăo Lotes $x$ Tratamentos, sendo que no lote MA todos os tratamentos foram numericamente superiores à testemunha, apresentando ainda diferença significativa entre esta e os tratamentos Thiram (180 g de i.a/100 kg de sementes) e Iprodione (100 g de i.a/100 kg de sementes). Com relação ao lote MB, todos os tratamentos nas dosagens maiores foram numericamente inferiores à testemunha, sendo que Captan C250 g de i.a/100 kg de sementes) foi significativamente inferior. Os fungicidas Captan e Thiram não apresentaram o mesmo comportamento dos demais, já que nas dosagens mais baixas tambem provocaram reduç̋es no vigor, embora năo significativas estatisticamente.

Na média dos dois lotes estudados houve uma tendencia das sementes tratadas com os fungicidas, nas dosagens maiores, em apresentar menor vigor em relaçăo aquelas tratadas com dosagens mais baixas. O fungicida Iprodione (100 g de i.a/100 kg de sementes) foi o único que proporcionou um aumento significativo no vigor das sementes nos dois lotes estudados. Em trabal ho com soja, EDJE \& BURRIS (1971) verificaram diferentes respostas ao tratamento fungicida em sementes com diferentes niveis de deterioraçăo causado pelo teste de envelhecimento acelerado. Segundo Delouche, citado por HEYDECKER (1972), uma das consequéncias da deterioraçăo das sementes é a degradação das membranas celulares com subsequente aumento da permeabilidade, juntamente com uma maior suscetibilidade a estresses ambientais; isto pode 
45.

explicar uma maior sensibilidade das sementes aos fungicidas nas dosagens mais elevadas.

Por outro lado, MARCOS FILHO \& SHIOGA (1981), em trabalho com tratamento fungicida em sementes de soja no teste de envel hecimento acelerado, mencionaram que as sementes tratadas apresentaram porcentagens médias de germinação mais elevadas após o referido teste. Com isto, pode-se ponderar que o fungicida protegeu as sementes, atenuando os efeitos da deterioração.

\subsubsection{Condutividade elétrica}

Os resultados referentes a condutividade el btrica se encontram na Tabela 12; como não houve interaça Lotes $\times$ Tratamentos, a discussão foi feita com base na média dos dois lotes estudados. 
46.

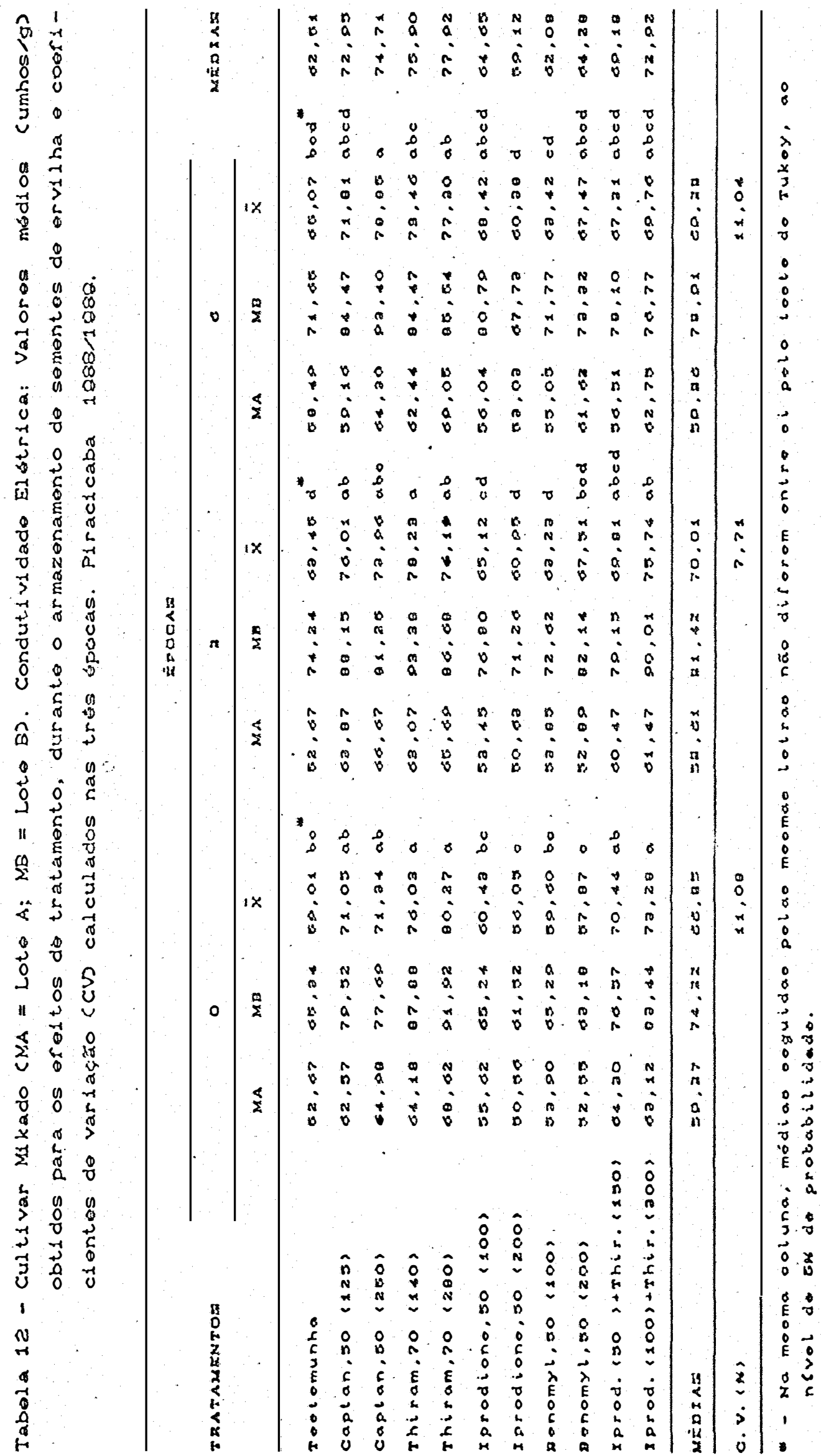


No infcio do período de armazenamento pode-se verificar, embora sem significado estatı́stico em relação à testemunha, um melhor desempenho proporcionado pelos fungicidas Iprodione (200 g de i.a $100 \mathrm{~kg}$ de sementes) e Benomyl (200 $\mathrm{g}$ de $i . \mathrm{a} / 100 \mathrm{~kg}$ de sementes). Os demais tratamentos apresentaram um valor numérico maior na condutividade elétrica da soluçăo, indicando assim um vigor mais baixo destas sementes. Convém destacar que o fungicida Thiram nas duas dosagens testadas e a mistura Iprodione + Thiram na dosagem mais elevada proporcionaram vigor de sementes estatisticamente mais bai xo do que aquel as sementes não tratadas quimicamente. Estas diferenças observadas entre os tratamentos fungicidas se devem apenas às variaçäes entre as sementes amostradas, já que estes produtos năo exercem influencia na condutividade elétrica da sol ução.

Já aos três meses de armazenamento, verificou-se um pequeno aumento no vigor das sementes, proporcionado pelos fungicidas Iprodione (200 $\mathrm{g}$ de $\mathrm{i} . \mathrm{a} / 100 \mathrm{~kg}$ de sementes) e Benomyl (100 g de i.a/100 kg de sementes), embora estes não diferissem estatisticamente da testemunha. Os fungicidas Captan o Thiram, nas duas dosagens, bem como a mistura Iprodione + Thiram (100+300 g de i.a/100 kg de sementes) reduziram significativamente o vigor das sementes.

No final do perfodo de armazenamento, o fungi-. cida Captan (250 g de i.a/100 kg de sementes) foi o único produto que reduziu significativamente o vigor das sementes. Resultados contrários foram encontrados por LOEFFLER et ali 
(1988) em soja, os quais observaram um pequeno efeito benérico do fungicida Captan na qualidade das sementes, embora a análise de variåncia năo tenha revelado diferença significativa. McDonald \& Wilson, citados por estes autores também verificaram um pequeno efeito na condutividade elétrica em sementes de soja tratadas com Captan. Thiram e Carboxin.

Observa-se que houve uma tendéncia dos fungicidas Iprodione e Benomyl em proporcionar um melhor desempenho nas sementes tratadas com estes produtos.

Em média, pode-se verificar um aumento na condutividade elét.rica da sol ução durante o período experimental na maioria dos tratamentos, permitindo assim verificar um decréscimo no vigor das sementes durante o armazenamento.

\subsubsection{Emergencia das plântulas em campo}

Quanto à emergéncia das plântulas em campo, observou-se também que não houve interação Lotes $x$ Tratamentos. Os resultados obtidos se encontram na Tabela 13.

Com relação as épocas estudadas, a terceira época, ou seja, no período normal de semeadura, onde as condiçớes climáticas foram mais favoráveis à emergência, verificou-se um melhor desempenho em relaçăo às duas épocas anteriores. Vale salientar que, em todas as épocas testadas, - uso de irrigação se fez necessário, garantindo assim uma emergéncia normal das plantulas. 
49.

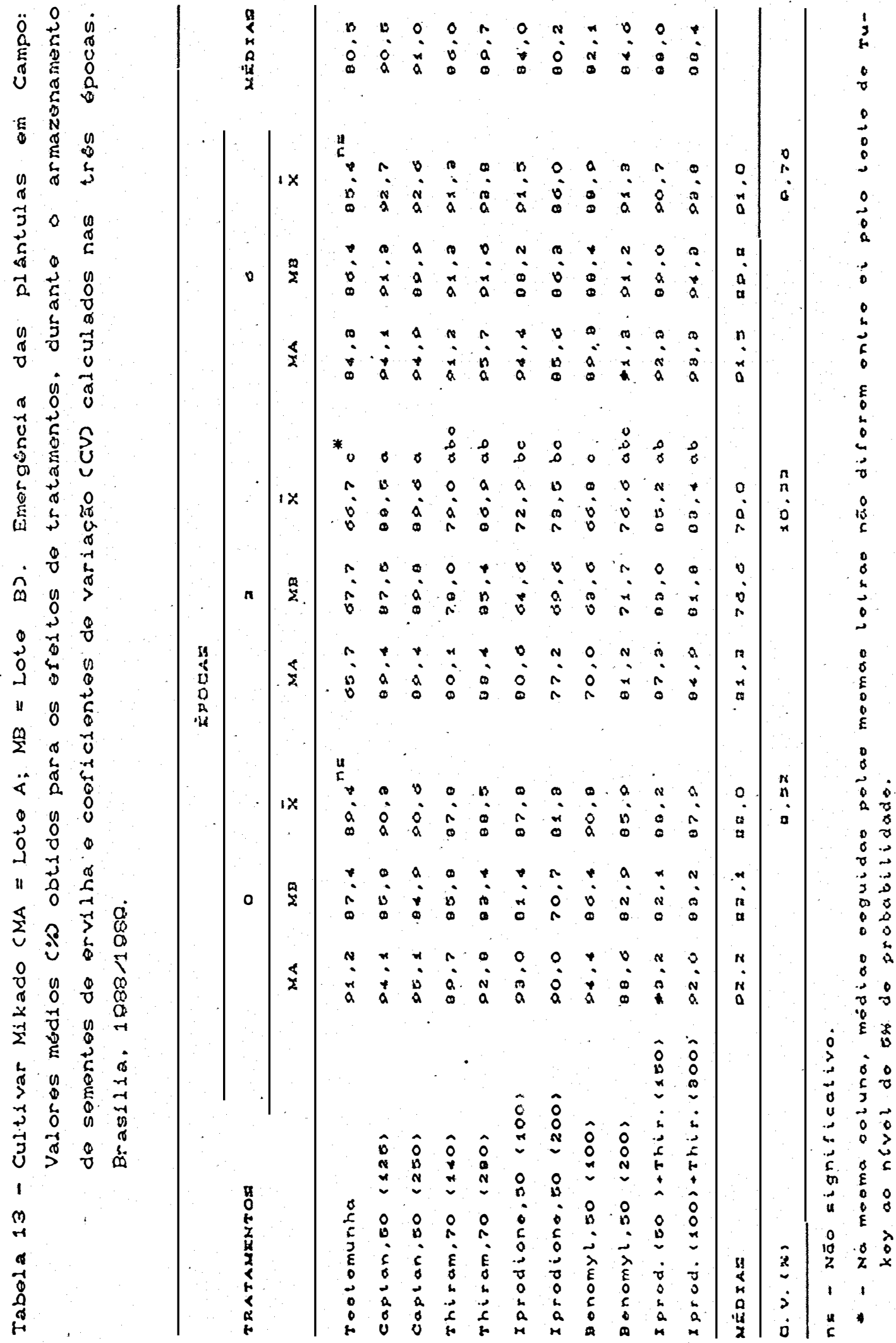


Năo se observou diferença significativa entre os tratamentos na primeira época estudada. No infcio do armazenamento, apenas os fungicidas Captan c125 e $250 \mathrm{~g}$ de i. $a / 100 \mathrm{~kg}$ de sementes) e Benomyl (100 g de i.a/100 kg de sementes) proporcionaram uma emergéncia de plántulas numericamente superior a testemunha.

Já aos trés meses após o armazenamento, verificou-se um aumento na emergencia em todos os tratamentos com fungicidas em relação à testemunha, sendo que as sementes tratadas com Captan 6125 e $250 \mathrm{~g}$ de i.a/100 kg de sementes), Thiram (280 $\mathrm{g}$ de i.a/100 kg de sementes) e Iprodione + Thiram (50+150e $100+300 \mathrm{~g}$ de i.a/100 kg de sementes) diferiram estatisticamente da testemunha csementes não tratadas).

Na época normal de semeadura, ou seja, após o final do perfodo de armazenamento, apesar da arílise de variáncia năo ter revelado diferença significativa entre os tratamentos, verificou-se que todos os fungicidas proporcionaram um aumento na emergéncia das plántulas. Vários trabaIhos tem demonstrado este efeito benéfico do tratamento fungicida em sementes de ervilha sobre a emergencia das plantulas em campo CWALKER et alii, 1940; BAYLIS et alii, 1943; FORSBERG et alii, 1944 ; LOCKE et alii, 19793.

Em média para os dois lotes estudados, somente - fungicida Captan é que proporcionou, nas trés épocas testadas um aumento na emergéncia. Este fungicida, considerado de amplo espectro de ação, apresenta. um controle satisfató- 
51.

rio para vários microorganismos causadores de tombamento. Por outro lado, PITA et alii (1986), verificaram que este produto mostrou-se ineficiente no controle de Rhizoctonia solani em ervilha, considerado um dos mais importantes patogenos em nossas condiçชes.

Apesar das épocas em que as sementes.foram semeadas em campo não houvessem temperaturas extremamente baixas, interessante se faz comentar que tais condiçzes, geralmente encontradas em palses de clima temperado e microclimas tropicais, diminuem a velocidade de emergéncia, fazendo com que as sementes e plântulas permaneçam durante mais algum tempo no campo, ficando assim sujeitas ao ataque de microorganismos, principalmente aqueles causadores de tombamento. HAGEDORN (1984) citou que baixas temperaturas por ocasião da semeadura favorecem. o ataque de Pythiun spp., com consequente aumento de tombamento, podendo ser isto, em parte, devido à germinação mais demorada das sementes.

\subsubsection{Determinaçăo do grau de umidade}

O grau de umidade das sementes nos dois lotes estudados deste cultivar apresentou pequenas variaçoes em função dos tratamentos fungicidas. utilizados, acompanhando as variaçôs de umidade relativa do ambiente nas respectivas. epocas analisadas (Tabela 14 ). 
52.

Tabela 14 - Cultivar Mikado (MA = Lote A, MB = Lote B). Grau de Umidade: Valores médios (\%) obtidos durante 0 armazenamento de dois lotes de sementes de ervitha. Piracicaba $1988 / 1989$.

\begin{tabular}{|c|c|c|c|c|c|c|}
\hline \multirow{3}{*}{ TRATAMENTOS } & \multicolumn{6}{|c|}{$\dot{E} P O C A s$} \\
\hline & \multicolumn{2}{|c|}{0} & \multicolumn{2}{|c|}{$\mathbf{3}$} & \multicolumn{2}{|c|}{0} \\
\hline & MA & MB & MA & $\mathbf{M B}$ & MA & MB \\
\hline Testemunta & 0.7 & 0,7 & 13,2 & 13,4 & 12,6 & 12,4 \\
\hline Captan,50 (125) & 0.4 & 0,0 & 13,2 & 12.0 & 12,0 & 11,0 \\
\hline Captan,50 (250) & 0.7 & 0,7 & 13,3 & 13,4 & 11,5 & 12,0 \\
\hline Thiram, 30 (140) & $0, \sigma$ & 0,8 & 12,8 & 12,5 & 12,0 & 12,5 \\
\hline Thiram, 70 (280) & 0.7 & 0,0 & 13,1 & $13 \cdot 2$ & 12,0 & 12,1 \\
\hline Iprodione.50 (100) & $0, \sigma$ & 10,0 & 12,0 & 12,5 & $12 ; 8$ & $1: 2,5$ \\
\hline Iprodione.50 $\{200\}$ & 0,7 & 0,8 & 12,4 & 13,1 & 11,0 & 12,0 \\
\hline Benomyl.50 (100) & 0,5 & 0.0 & 13.0 & 13,1 & 12,0 & 12,0 \\
\hline Benomyl, 50 (z00) & 0,6 & 0,8 & 13,2 & 13,2 & 12,2 & 12,7 \\
\hline Iprod. $(50)$ thhir.(150) & 0,4 & 0,0 & 12,5 & 12,8 & 12,0 & 12,0 \\
\hline Iprod. $(100)+$ This. (300) & $0, \sigma$ & $10 \cdot 2$ & 13,0 & 12,7 & 12,0 & 22,4 \\
\hline MÉDIAS & 0,6 & 0,0 & 13.0 & 13,0 & 12,4 & 12,4 \\
\hline
\end{tabular}

- teor médio de água das sementes durante o perlodo experimental variou em média de 9,6 a $13,0 \%$, condiçôes estas favoráveis para a manutenção da qualidade fisiológica das sementes de ervilha no armazenamento (DELOUCHE et alii, 1973). Convém salientar ainda que o grau de umidade das sementes verificado durante o armazenamento fez com que a atividade da maior parte dos microorganismos diminuisse ou mesmo tornasse nula (Tabelas 15 e 16). HARRINGTON (1972), citou que sementes com teor de água abaixo de 12 - $18 \%$ não favorecem o desenvolvimento de fungos. 
53.

\subsubsection{Sanidade das sementes}

Apesar dos dados não terem sido submetidos à

análise de variância, procurou-se verificar as possiveis tendéncias, sendo que as médias obtidas no exame de sanidade das sementes dos dois lotes desta cultivar se encontram nas Tabelas 15 e 16.

\subsubsection{Lote MA}

Além dos microorganismos descritos na Tabela 15, outros fungos como Ascochyta spp., Botrytis spp. e Rhizoctonia solani também for am recuperados nas sementes não tratadas, com incidencia de $1,0,2,0$ e 2,0\%, respectivamente. Assim sendo, todos os tratamentos testados foram eficientes no controle destes patógenos. Verificou-se ainda que Botrytis spp. e Rhizoctonia solani tiveram sua incidencia reduzida a zero após t.rés meses de armazenamento, enquanto que Ascochyta spp. permaneceu com a mesma incidencia neste perlodo, e que somente após seis meses de armazenamento não houve recuperação do patógeno. A ausência destes microorganismos nas sementes após seis meses de armazenamento pode ser devida ao bai xo potencial de inóculo observado no inf́cio do perído de armazenamento, já que, segundo NEERGAARD (1979), os fungos Botrytis cinerea em algumas especies e Ascochyta pisi em ervilha, podem permanecer viáveis nas sementes por perlodos de até 2 e 7 anos, respectivamente, dependendo das condiç̧̌es de armazenamento. 


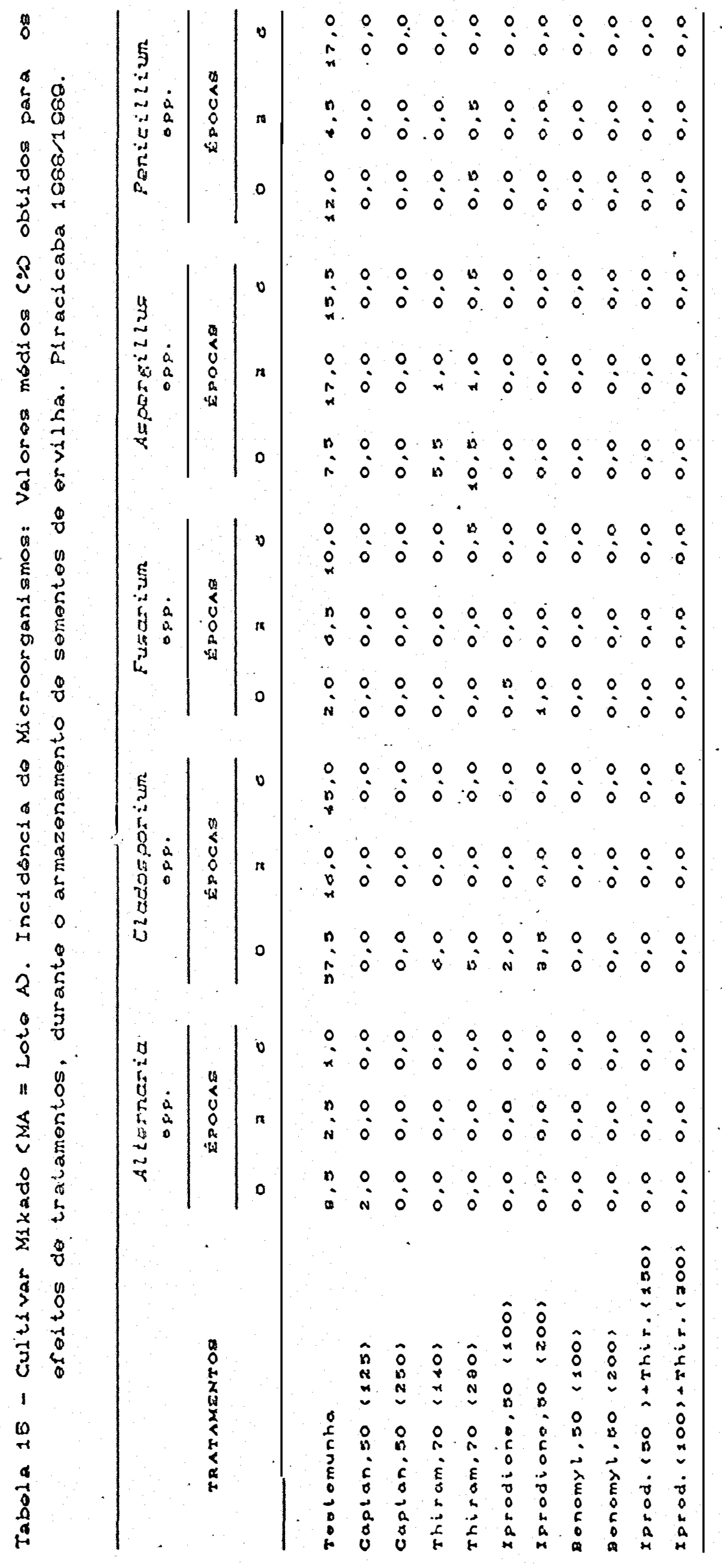

54. 


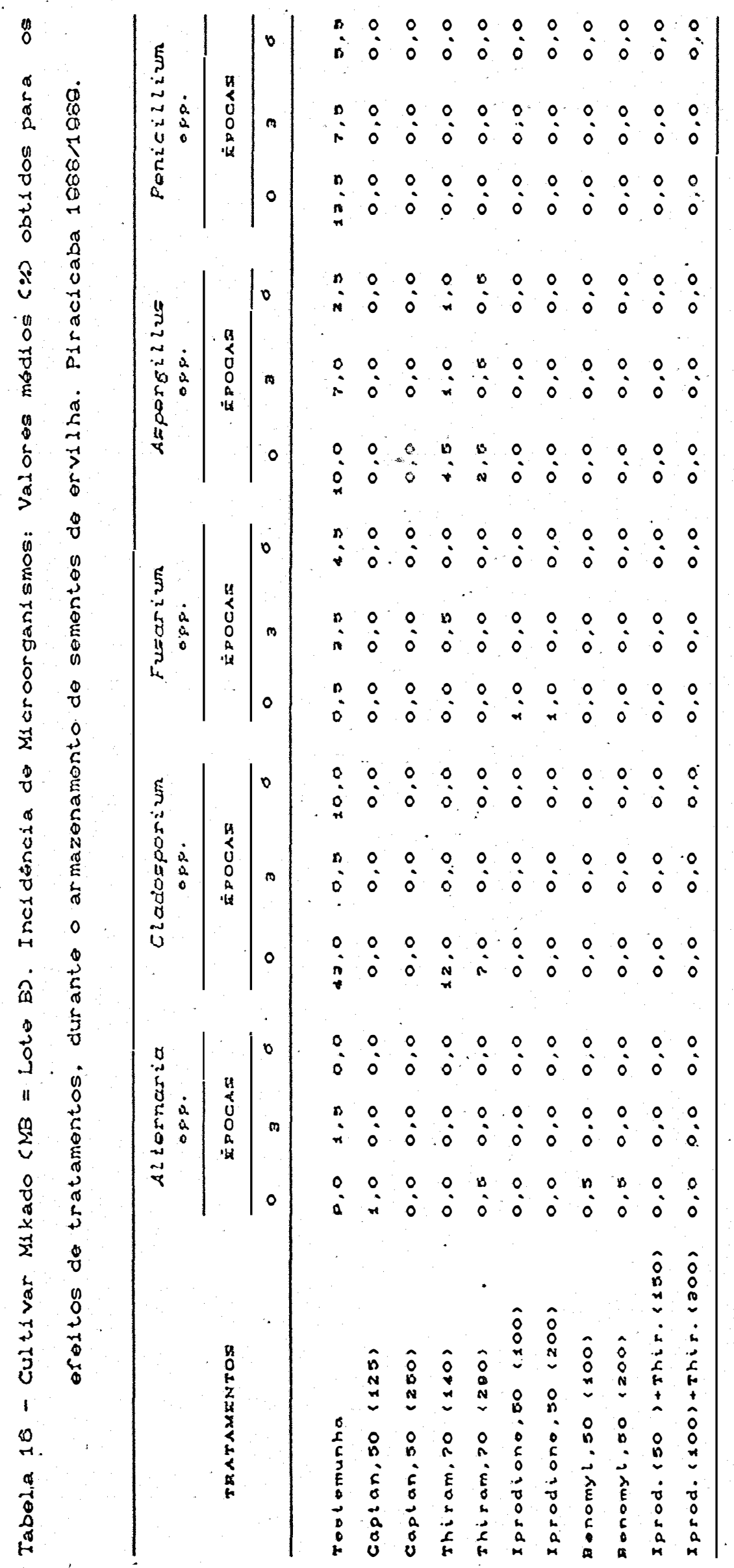

55. 
Com rel açao a Al ternaria spp. , observou-se uma redução do patógeno com o decorrer do armazenamento. Resultados semelhantes foram obtidos em sementes de cenoura (CUNHA et alii, 1987) e feijăo (NOVEMBRE, 1987). Entretanto, segundo NEERGAARD (1979), diferentes especies de Alternaria podem sobreviver em sementes de diversas espécies até 8 anos; inclusive, são considerados pelo autor, fungos de vida longa.

Quanto ao controle de Alternaria spp., observou-se que o fungicida laptan $(125 \mathrm{~g}$ de i.a/100 kg de sementess apesar de reduzir a incidencia deste microorganismo nas sementes, não eliminou totalmente o mesmo; os demais tratamentos proporcionaram um excelente controle do fungo, reduzindo a incidencia a zero. Em trabalho com feijăo, MENTEN \& MENDES (1982) também conseguiram bom controle deste fungo com o fungicida Thiram. NOVEMBRE (1987) citou a mistura Thiram + Benomyl como a mais eficiente no controle de Alternaria em feijăo. Resultados semelhantes foram obtidos em soja com Thiram, exercendo o melhor controle, e Benomyl com um controle não satisfatório (ELLIS et alii, 1975 ).

Os produtos a base de Iprodione, conforme pode ser observado, foram altamente eficientes no controle de Alternaria spp.; segundo citaçăo de ROWE (1983), este produto apresenta um excelente controle de Alternaria, Heiminthosporium e Rhizoctonia.

Foi verificada uma alta incidencia de cladosporium spp. nas sementes não tratadas, no infcio do armaze- 
namento; observou-se ainda uma redução do microorganismo com - decorrer do armazenamento, mas ainda com uma incidéncia considerável no final do mesmo. Os fungicidas Thiram e Iprodione, nas duas dosagens testadas, proporcionaram uma grande redução da incidencia do microorganismo, sem contudo eliminá-1o; já a mistura dos dois fungicidas propiciou um excelente controle, podendo al verificar um efeito sinergistico da mistura. Os fungicidas Captan, Benomyl e Iprodione + Thiram, nas duas dosagens testadas permitiram um excelente controle, reduzindo a incidéncia deste patógeno a zero. Em trabalho com soja, ELLIS et alii (1975) eliminaram a incidencia deste patógeno nas sementes utilizando os fungicidas Captan, Thiram e Benomyl.

Para o fungo Fusarium spp., verificou-se um aumento do mesmo em função do periodo de armazenamento, contrariando os resultados obtidos por vários autores, dentre eles NOVEMBRE (1987) e MORAES (1989) em sementes de fẹ jăo e soja, respectivamente.

Segundo CHRISTENSEN \& KAUFMANN (1963), o fungo Fusarium desaparece dos grăos em poucos meses, quando as condiç̧̋es são pàra o armazenamento de alimentos. NEERGAARD (1979) mencionou que a maior parte das espécies do género Fusarium tem um periodo de longevidade muito curto, com um máximo de dois anos.

Quanto ao controle, os fungicidas Thiram C280 $g$ de i.a $100 \mathrm{~kg}$ de sementes) e Iprodione (100 e $200 \mathrm{~g}$ de i. a $/ 100 \mathrm{~kg}$ de sementess proporcionaram uma redução do micro- 
58.

organismo, sem contudo elimina-los; os demais tratamentos reduziram a incidência do fungo a zero. Para o controle deste patógeno, diferentes trabalhos citaram a eficiencia do fungicida Benomyl CELLIS et alii, 1975 e NOVEMBRE, 1987 em feijăo FURLAN et alii, 1985 em algodá).

Quanto aos fungos de armazenamento, Aspergilius spp. e Penicillium spp., observou-se um aumento destes em relaçăo ao perído de armazenamento; este fato também foi observado por CHRI STENSEN (1972) e MORAES (1989) em sementes de soja.

Com exceça do fungicida Thiram, todos os demais foram eficientes na eliminaçăo de Aspergillus spp., o mesmo foi observado por ELLIS et alii (1975). Este produto reduziu a incidencia do patógeno a niveis bastante baixos, sendo que Thiram (140 g de i.a $100 \mathrm{~kg}$ de sementes) proporcionou uma excelente reduçăo após seis meses de armazenamento. Este mesmo produto, na menor dosagem, proporcionou a eliminaçăo de Penicillium spp., no inflcio do armazenamento, sendo que o mesmo na maior dosagem reduziu bastante a incidência do patógeno, porém a eliminaçăo completa ocorreu apenas aos seis meses. Segundo NOVEMBRE (1987), e di versos autores citados por este, o fungicida Captan tem se mostrado com uma maior eficiencia no controle de Penicillium.

\subsubsection{Lote MB}

Pode-se observar neste lote uma baixa incidencia de Ascochyta spp. (1,0\%) e Botrytis spp. (0,5\%) nas se- 
59.

mentes não tratadas, no inficio de perlodo de armazenamento. Todos os fungicidas testados foram eficientes no total controle destes microorganismos.

Outros microorganismos foram detectados nas sementes, e as médias obtidas se encontram na. Tabela 16.

Para o fungo Alternaria spp., observou-se uma redução do mesmo durante o periodo de armazenamento, sendo que aos seis meses esta incidencia foi reduzida a zero. Todos os fungicidas testados foram eficientes na reducăo deste microorganismo. No inicio do armazenamento, os fungicidas Captan (250 $\mathrm{g}$ de i.ar100 kg de sementes), Thiram (140 g de i.ar100 kg de sementes), Iprodione (100 e $200 \mathrm{~g}$ de i. a $/ 100 \mathrm{~kg}$ de sementes) e Iprodione + Thiram (50 + 150 e 100 $+300 \mathrm{~g}$ de i.a/100 kg de sementes) proporcionaram um efici-ente controle do fungo; os demais somente foram eficientes na eliminação do patógeno aos trés meses após o armazenamento.

Com relação a Cladosporium spp., verificou-se uma alta incidencia nas sementes no infio do armazenamento. Todos os tratamentos, com exceção de Thiram, foram eficientes na eliminação do patógeno. Somente após trés meses é que este produto proporcionou uma redução da incidéncia do microorganismo a zero.

Como o ocorrido no lote MA, também foi verificado um aumento de Fusarium spp. com o decorrer do armazenamento. Como este fungo tende a diminuir com o período de armazenamento, o que pode ter ocorrido é que com a 
60.

diminuição daqueles microorganismos de rápido crescimento, como Alternaria e Cladosporium, houve uma menor competição dos microorganismos, ou mesmo um menor mascaramento destes; com isto, houve um maior desenvolvimento de Fusarium nas sementes ou uma maior visualização do fungo. Os fungicidas Captan, Benomyl e a mistura Iprodione + Thiram, nas duas dosagens testadas, eliminaram o patógeno já na primeira. época estudada; já o fungicida Iprodione eliminou o patógeno somente após trés meses de armazenamento.

Para Aspergilius spp. e Penicillium spp., ao contrário do obtido no lote $M A$, observou-se uma redução dos mesmos, com o decorrer do periodo de armazenamento.

Quanto ao controle de Aspergillus spp., com exceção do produto Thiram, os demais foram eficientes na eliminação deste patógeno. Este produto, apesar de reduzir a incidencia do microorganismo, năo eliminou-o totalmente das sementes.

Com relação a Penicillium spp., todos os produtos testados foram eficientes na eliminação do patógeno.

\subsection{Cultivar Pomak}

Os valores de $F$ para efeito de tratamentos nos testes realizados nas respectivas épocas de análise encontram-se na Tabela 17. 


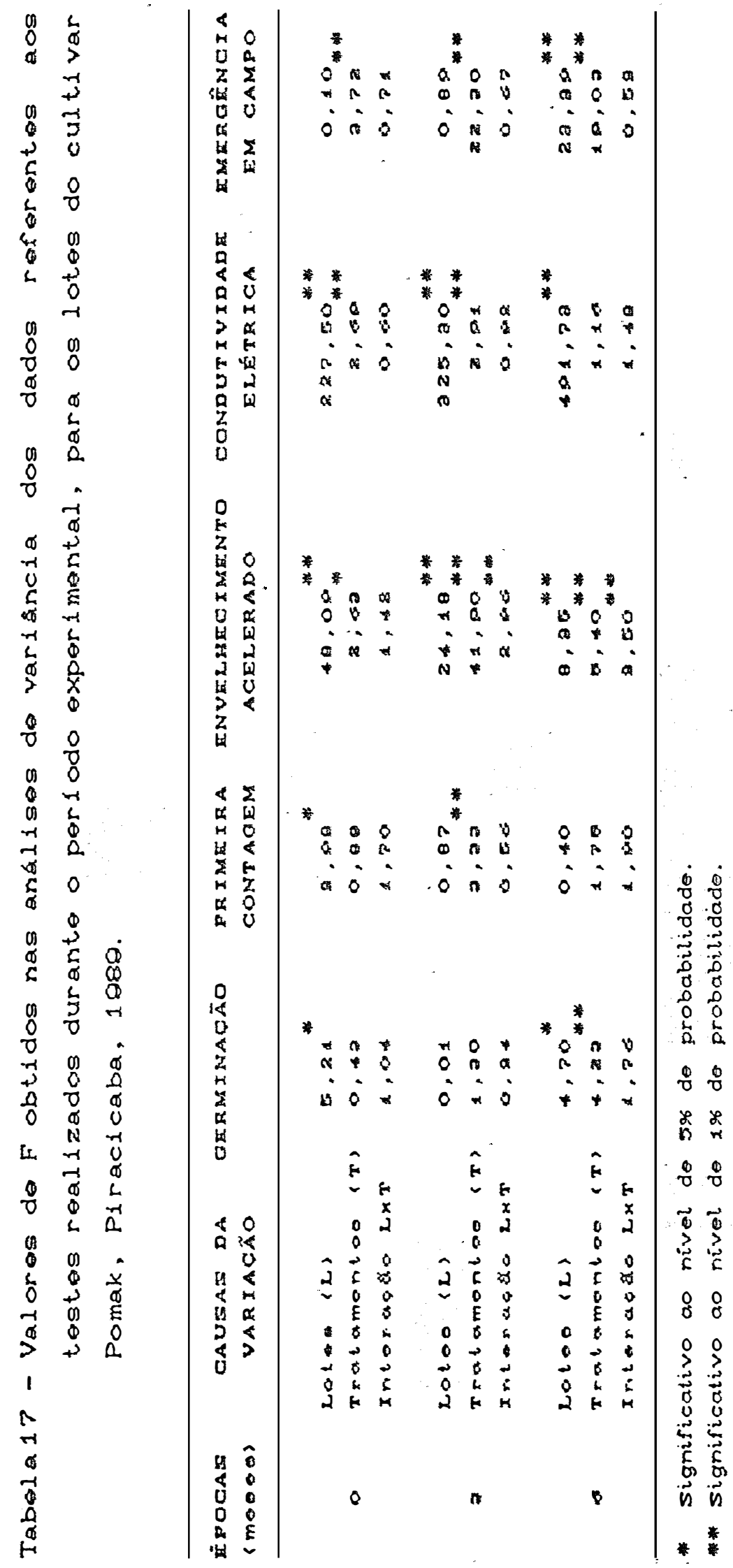

61. 
62.

\subsubsection{Germinaça}

Conforme se observa na Tabela 17, a interaçăo Lotes $x$ Tratamentos nåo foi significativa para este parametro; assim a discussăo foi feita com base na média dos dois lotes (Tabela 18).

No infcio do armazenamento, bem como aos tres meses, nåo se observou diferença significativa entre os tratamentos; entretanto nota-se aos tres meses que, com exceção do tratamento com Iprodione + Thiram c50 + $150 \mathrm{~g}$ de i. a $/ 100 \mathrm{~kg}$ de sementess, todos os demais foram numericamente inferiores à testemunha.

Já aos seis meses, no final do periodo de armazenamento, a análise de variancia revelou diferença significativa entre os tratamentos. Apesar da maioria dos tratamentos serem numericamente superiores à testemunha, somente o tratamento com Iprodione $(100 \mathrm{~g}$ de i.a/100 kg de sementes) diferiu estatisticamente da mesma. Verificou-se ainda nesta época, que para o lote PA, todos os tratamentos fungicidas proporcionaram um aumento numérico na porcentagem de germinação das sementes.

Ao longo do período de armazenamento, observou-se um decréscimo nas medias da porcentagem de germinaçăo, e a resposta aos tratamentos fungicidas também não foi muito positiva nas trés épocas estudadas, tal como ocorrido com o cultivar Mikado; e isto provavelmente deve estar relacionado com uma alta qualidade fisiológica destas sementes no infcio do armazenamento, conforme mencionado anteriormente. 
63.

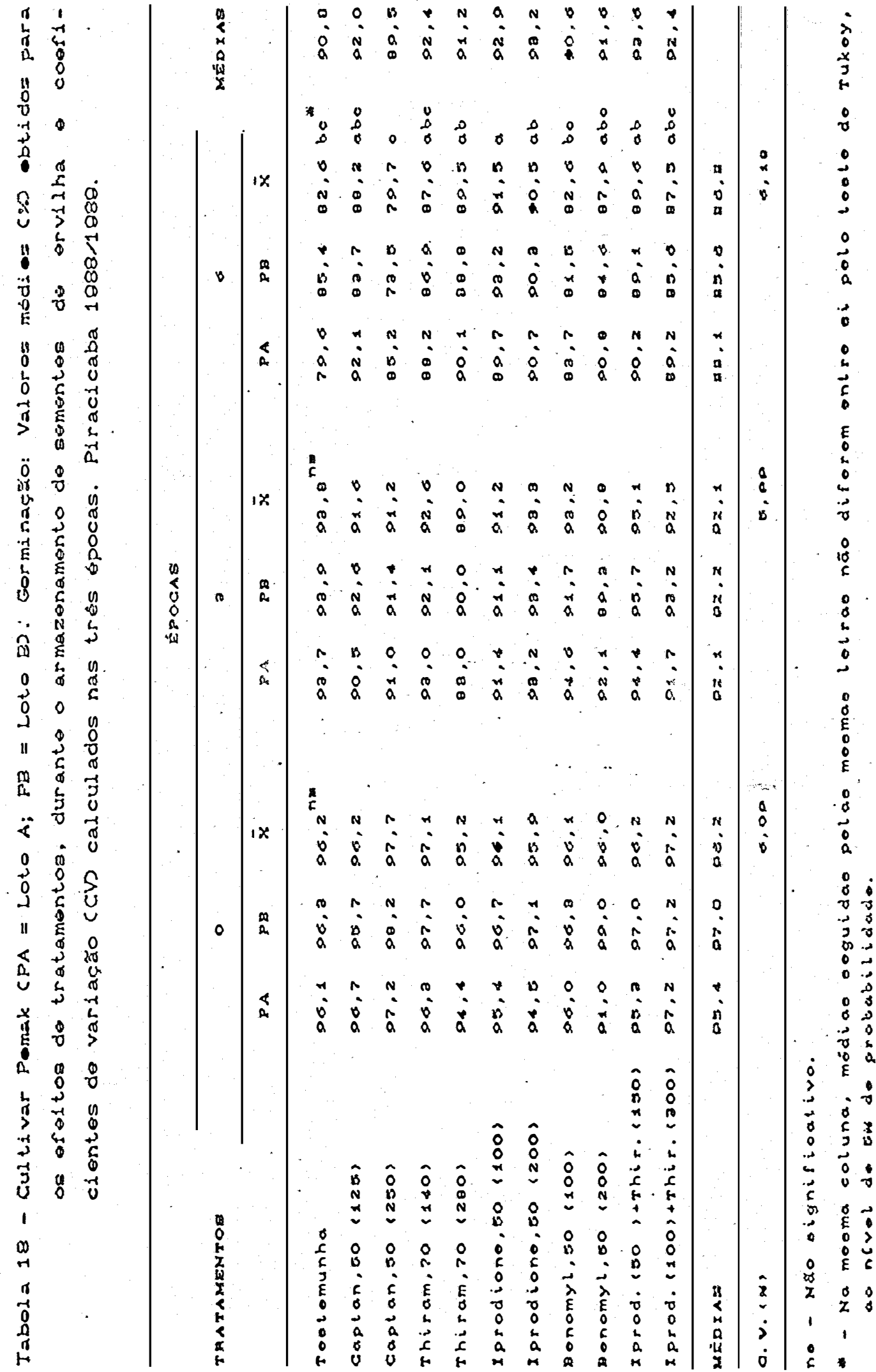


64.

4.2.2. Primeira contagem de germinaçăo

Assim como na germinaçăo, não houve interaça

Lotes $x$ Tratamentos nas tres épocas; portanto a discussão foi feita com base na média dos dois lotes (Tabela 19 ).

No infcio do armazenamento năo foi observada diferença significativa entre os tratamentos. Entretanto, verificou-se que, com exceça do tratamento com Iprodione + Thiram (50+150 g de i:a/100 kg de sementes), todos os demais foram numericamente superiores à testemunha.

Aos trés meses, apenas a mistura Iprodioné + Thiram (100+300 g de i.a/100 kg de sementes) diferiu estatisticamente da testemunha. Este produto causou uma reduçăo na primeira contagem de germinaçăo, afetando assim o vigor das sementes. Observou-se ainda que, com exceçao dos fungi-. cidas captan e Thiram, quando em dosagens menores, todos os demais proporcionaram uma reduçăo, embora não significativa, nạ primeira contagem de germinaçăo.

Por outro ládo, aos seis meses de armazenamento, verificou-se que a maioria dos tratamentos foi numericamente superior à testemunha. Tal como ocorrido com o cultivar Mikado, também foi observada uma redução na primeira contagem de germinaçăo quando se utilizou a mistura Iprodione + Thiram (100+300 g de i.a/100 kg de sementes). Resul-. tados semelhantes, citados anteriormente, também for am observados por MADEIRA et ali $i$ (1988). O fungicida Captan (250 g de i.a/100 kg de sementes também se mostrou fitotóxico. 
65.

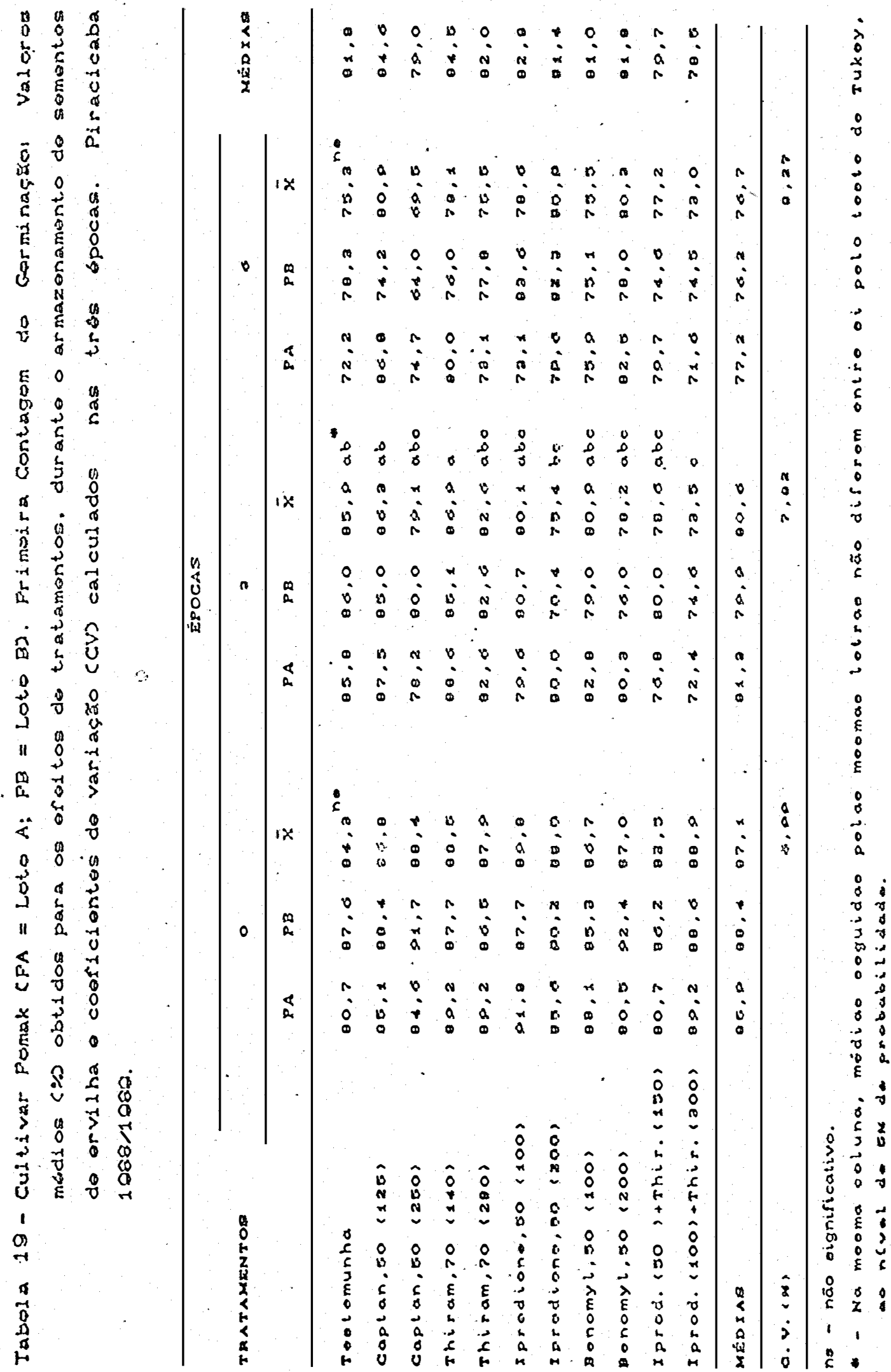


66.

\subsection{Envel hecimento acelerado}

Os dados referentes ao teste de envel hecimento acelerado se encontram na Tabela 20. Na primeira época nåo houve interação Lotes $x$ Tratamentos. Nas demais épocas a discussão foi feita separadamente para cada lote.

Conforme se observa no infcio do armazenamen-. to, apenas os tratamentos Captan c250 g de i.a/100 kg de sementes) e Iprodione (100 $\mathrm{g}$ de $\mathrm{i} . \mathrm{a} / 100 \mathrm{~kg}$ de sementes) diferiram estatisticamente entre si. Com exceçăo deste úlimo e da mistura Iprodione + Thiram $\mathrm{C} 50+150 \mathrm{~g}$ de i. a $/ 100 \mathrm{~kg}$ de sementes), todos os demais for am numericamente inferiores à testemunha.

No lote PA, aos três meses, apesar dos fungicidas Captan (125 g de i.a/100 kg de sementes) e Thiram ( 140 e $280 \mathrm{~g}$ de $\mathrm{i}, \mathrm{a} / 100 \mathrm{~kg}$ de sementess. não terem diferido estatisticamente da testemunha, estes proporcionaram um aumento numérico no vigor; os demais produtos proporcionaram um aumento significativo no vigor das sementes. No lote PB os produtos laptan e Thiram nas duas dosagens nåo diferiram estatisticamente da testemunha. Os demais produtos proporcionaram um aumento significativo no vigor das sementes.

No final do período de armazenamento, verificou-se que apenas o produto Iprodione é que proporcionou vigor das sementes estatisticamente superior à testemunha, quando se utilizaram as dosagens de 200 e $100 \mathrm{~g}$ de i.a/100 kg de sementes para os lotes PA e PB, respectivamente. Na 
media geral, verificou-se que o fungicida Captan causou uma pequena reduçăo no vigor das sementes. A queda do vigor das sementes durante o armazenamento, aliado as condiçres drásticas do teste de envelhecimento acelerado, fizeram com que o vigor das sementes, nesta última época, mostrasse niveis extremamente baixos.

Assim como no cultivar Mikado, verificou-se também pela média dos dois lotes que a maioria dos produtos fungicidas proporcionou um aumento numerico no vigor das sementes.

Como se observa na Tabela 20 , o vigor médio das sementes decresceu acentuadamente ao longo do perílo de armazenamento e apesar das sementes tratadas com a maioria dos fungicidas também apresentarem reduçăo de vigor durante - armazenamento, estas foram menos afetadas pelo teste de envel hecimento acelerado que as sementes năo tratadas, portanto conservando o vigor das sementes por um maior periodo de tempo. 


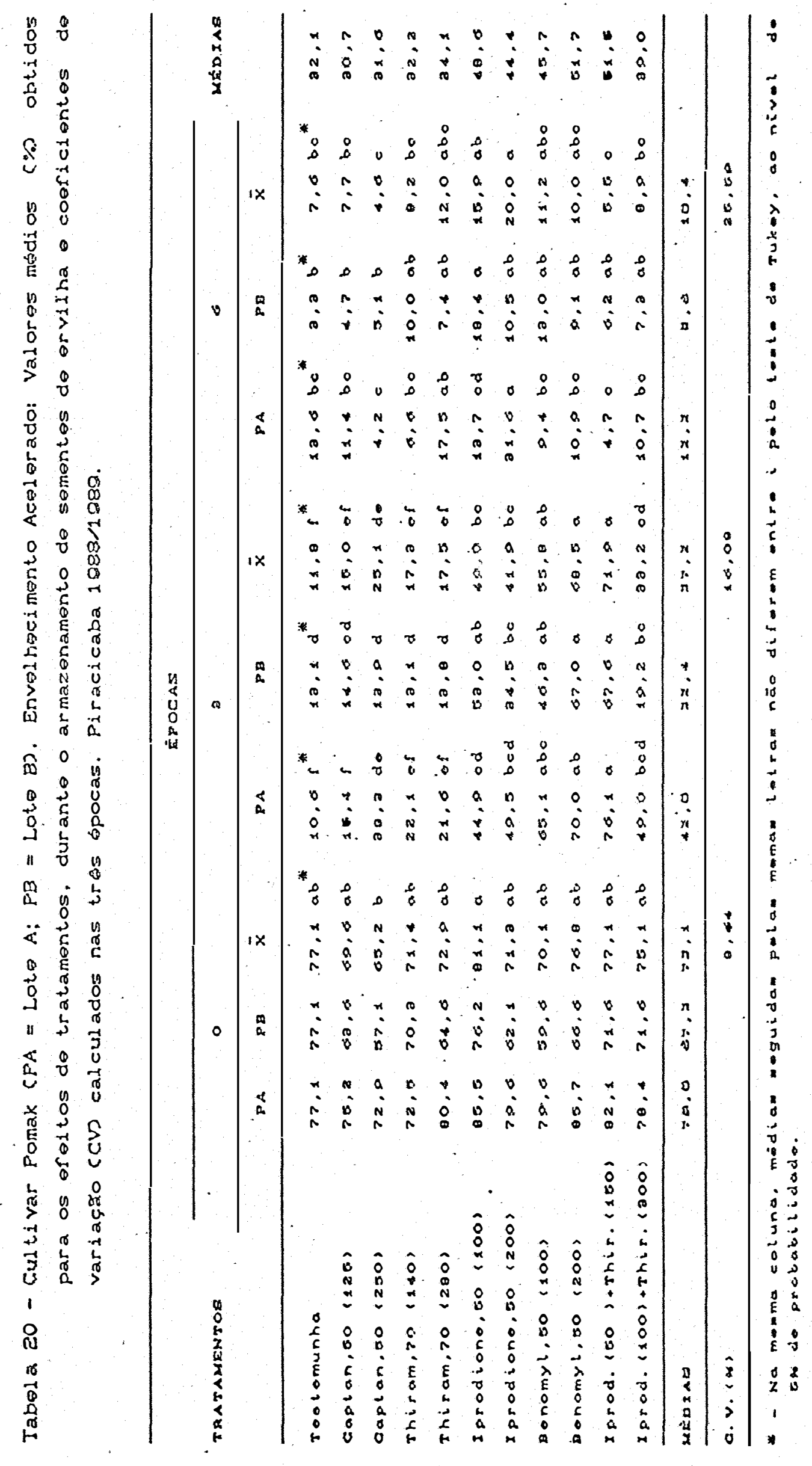

68. 
69.

\subsection{Condutividade elétrica}

Os resultados referentes à condutividade elétrica se encontram na Tabela 21. Observou-se que neste cultivar também não houve interação Lotes $x$ Tratamentos e, assim, a discussão foi feita com base na média dos dois lotes estudados.

Apesar de ter havido diferença significativa entre os tratamentos no infcio do armazenamento, todos os tratamentos fungicidas não diferiram da testemunha; houve sim um melhor desempenho numérico nas sementes tratadas com Iprodione (100 e $200 \mathrm{~g}$ de i.a/100 kg de sementes) e Benomyl (200 g de i.a/100 kg de. sementes. Os demais tratamentos causaram um decréscimo no vigor das sementes.

Resultado semel hante foi observado aos trés

meses de armazenamento, sendo que nesta época, apenas o fungicida Iprodione é que proporcionou um melhor desempenho numerico. Os demais tratamentos causaram um acréscimo na condutividade elétrica da soluçăo, ou seja, uma redução no vigor das sementes.

Verificou-se, ainda, que, ao final do armazenamento, as sementes tratadas com os fungicidas Iprodione (200 g de i.a/100 kg de sementes), Benomyl ( $100 \mathrm{~g}$ de i.a/100 kg de sementes) e Iprodine + Thiram (50 + $150 \mathrm{~g}$ de i.a/100 kg de sementes) apresentaram um melhor desempenho em relaçăo às sementes não tratadas, apesar da análise de variância. não ter revel ado diferença significativa. 


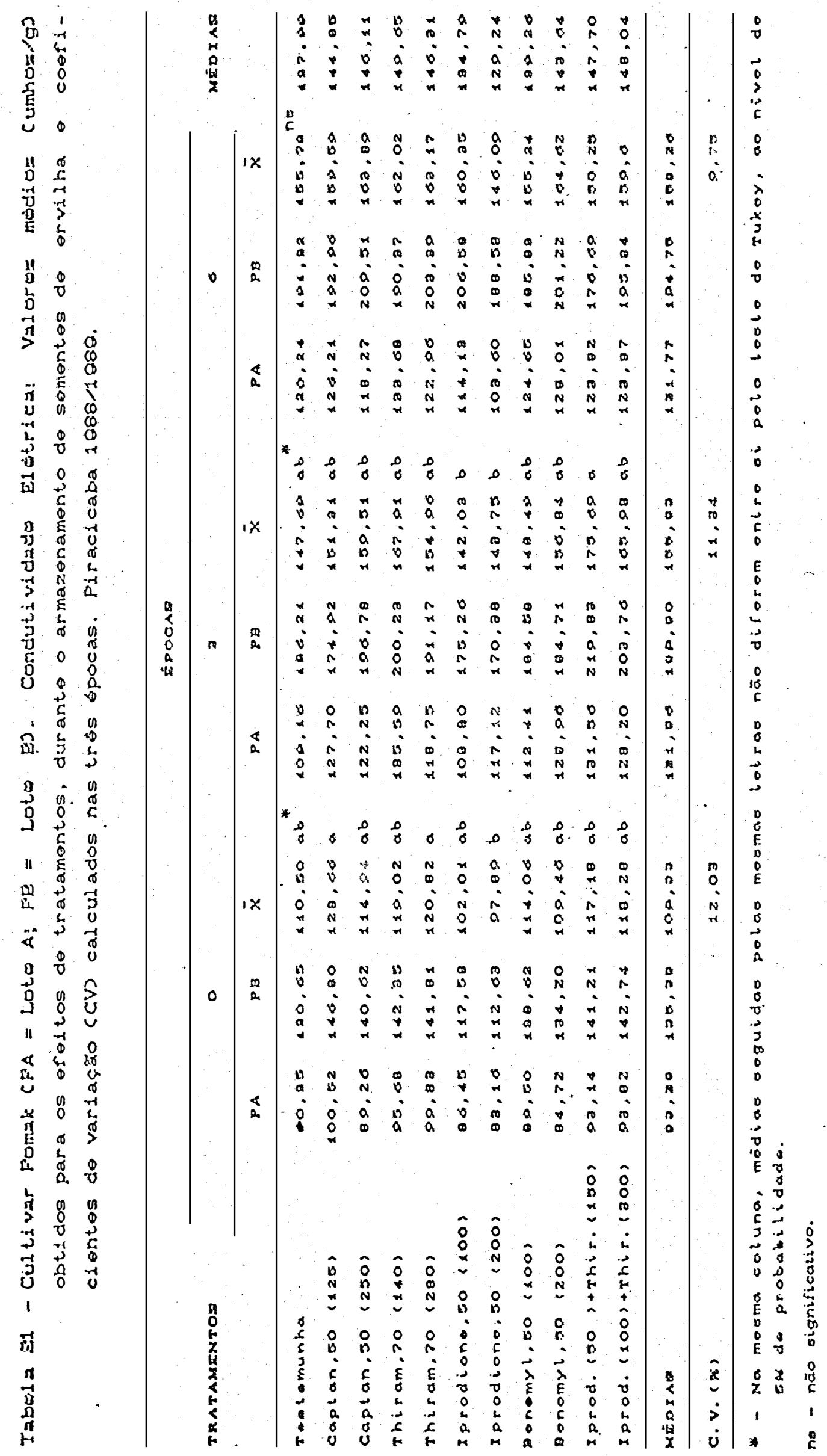


Como no cultivar Mikado, em média, pode-se observar um aumento na condutividade elétrica da soluçăo durante o periodo experimental na maioria dos tratamentos, permitindo assim verificar um decréscimo do vigor das sementes durante o armazenamento.

Comparando os dados referentes dos dois cultivares, observa-se que o cultivar Pomak apresentou nas tres épocas um maior valor na condutividade elétrica da soluçăo; isto se deve a dois fatos que podem estar relacionados entre si. Analisando os demais testes realizados, pode-se verificar que as sementes do cultivar Pomak sempre apresentaram uma média inferior de germinaça e vigor quando comparadas do cultivar Mikado; alem disto, as diferenças dos resultados na condutividade podem ter sido determinados por dois fatores relacionados ao genótipo, como por exemplo, a estrutura do tegumento e a composiçăo química das sementes.

\subsubsection{Emergencia das plantulas em campo}

Quanto à emergéncia das plantulas em campo, verificou-se também que năo houve interaçăo Lotes $x$ Tratamentos. Os resultados obtidos se encontram na Tabela 2e.

Apesar de ter ocorrido diferença significativa entre os tratamentos no infeio do armazenamento, nenhum dos tratamentos fungicidas diferiu da testemunha, embora os produtos Captan (125 e $250 \mathrm{~g}$ de i.a/100 kg de sementes), Thiram (140 g de i.a/100 $\mathrm{kg}$ de sementes) e a mistura Iprodione + 
Thiram (50 + 150 e $100+300 \mathrm{~g}$ de i.a/100 kg de sementes) tenham proporcionado um maior valor numerico na emergéncia das plantulas.

Assim como no cultivar Mikado, estes mesmos produtos também proporcionaram uma maior emergéncia das plântulas em campo em relação à testemunha após três meses de armazenamento. As sementes tratadas com os fungicidas Iprodione e Benomyl, apresentaram um valor inferior, embora não significativo entre estes e a testemunha. Vale salientar que estes dois produtos săo especificos e năo de amplo espectro de açăo como os demais, e o controle dos varios microorganismos do solo torna-se ineficiente, e isto pode explicar a menor emergencia das plantulas com as sementes tratadas com estes fungicidas.

Js aos seis meses após o armàzenamento, verificou-se um desempenho maior na emergencia proporcionado por todos os fungicidas, com exceçăo de Benomyl $1100 \mathrm{~g}$ de i.a $100 \mathrm{~kg}$ de sementess. Os fungicidas Captan, Thiram e Iprodione + Thiram foram estatisticamente superiores à testemunha, confirmando al a explicaçăo dada anteriormente. 
73.

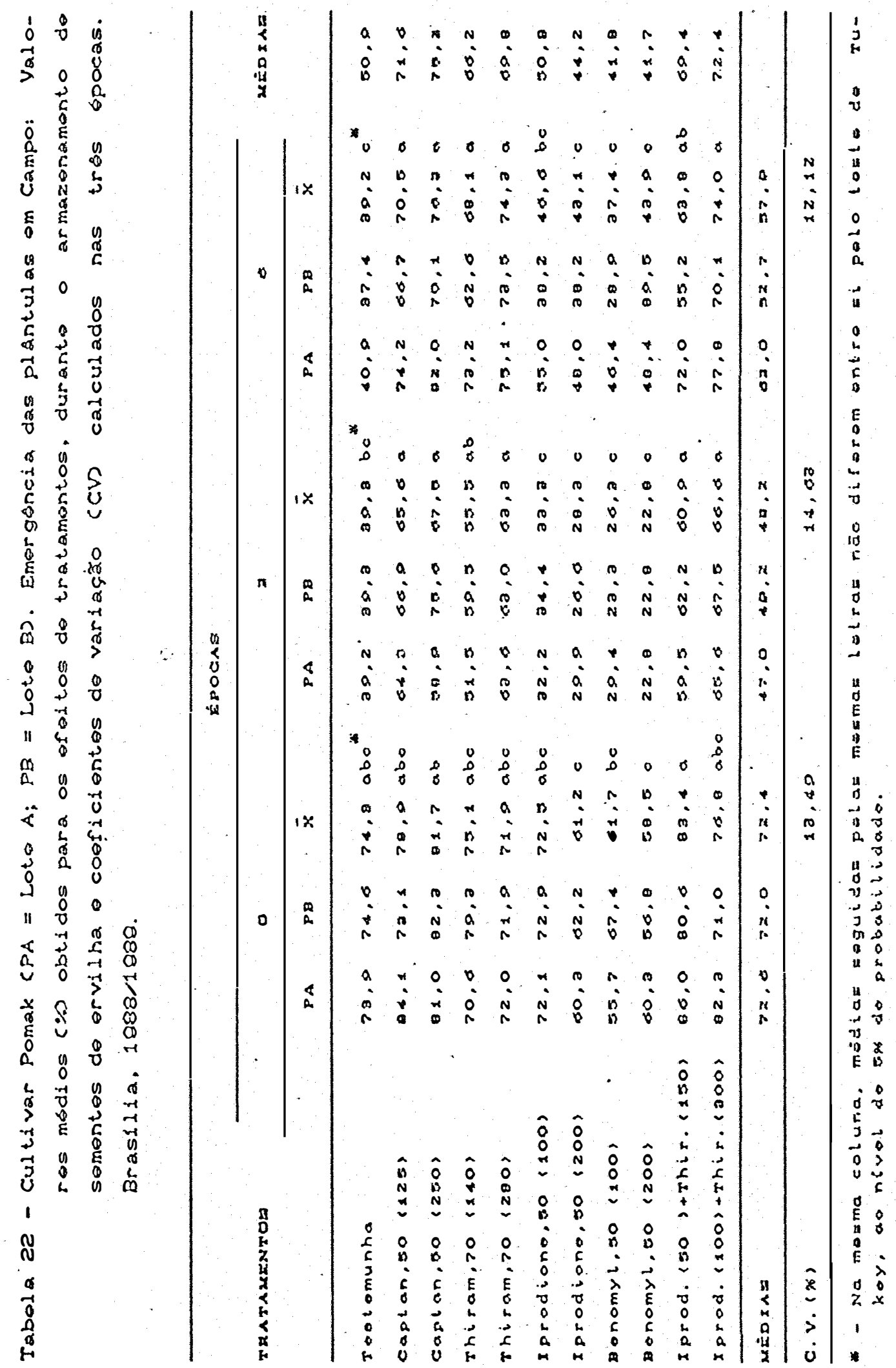


74.

Analisando a Tabela 22, verificou-se que este cultivar apresentou um potencial de emergencia inferior ao cultivar Mikado, caracterizando mais uma vez úm menor vigor nas sementes do cultivar rugoso, Pomak. Entretanto, observou-se que alguns produtos fungicidas atenuaram este baixo vigor, fazendo com que houvesse uma maior emergencia propiciada por estes produtos. Além disto, conforme SHORT \& LACY (1974), SHORT \& LACY (1976), KRAFT (1974), LORIA \& LACY (1979), HINDELS \& KOMMEDAHL (1978), HINDELS \& KOMMEDAHL (1982) e KRAFT (1982), sementes rugosas por possuirem um maior teor de açúcares são mais suscetiveis ao ataque de microorganismos como tambem se beneficiam do tratamento fungicida.

4.2. 6. Determi naçăo do grau de umi dade

Como no cultivar Mikado, pode-se observar que - grau de umidade das sementes nos dois lotes estudados deste cultivar apresentou pequenas variaçöes em funçăo dos tratamentos fungicidas utilizados, acompanhando as variaçठes de umidade relativa do ambiente nas respectivas epocas analisadas (Tabela 23). 
75.

Tabela 23 - Cultivar Pomak $(P A=$ Lote A; PB = Lote B). Grau de Umidade: Valores médios (\%) obtidos durante o armazenamento de dois lotes de sementes de ervitha. Piracicaba, $1988 / 1989$.

\begin{tabular}{|c|c|c|c|c|c|c|c|}
\hline \multirow{3}{*}{ TRATAMENTOS } & \multicolumn{2}{|c|}{. } & $\overline{\mathbf{E}} \boldsymbol{P}$ & 0 & C A S & & \\
\hline & \multicolumn{2}{|c|}{0} & \multicolumn{3}{|c|}{$\mathbf{3}$} & \multicolumn{2}{|c|}{0} \\
\hline & $\mathbf{P A}$ & $\mathbf{P B}$ & $\mathbf{P A}$ & & $\mathbf{P B}$ & $\mathbf{P A}$ & PB \\
\hline Testemunha & 10,0 & 0,0 & 14,0 & & 13,7 & 22,0 & 12,0 \\
\hline captan, 50 (125) & 10,3 & م, & 13,4 & & $13 \cdot \sigma$ & 12,3 & 12,0 \\
\hline Captan,50 (250) & 10,3 & 9,8 & 14,2 & & 13,8 & 12,8 & 12,7 \\
\hline Thiram, $70(140)$ & 0,0 & 0,5 & 13,4 & & $13 \cdot 4$ & 13,1 & 12,0 \\
\hline Thiram, $70(280)$ & 0,0 & 0,0 & 13,0 & & 13,0 & 12,0 & 12,4 \\
\hline Iprodione, 50 (100) & 10,0 & 10,4 & 13,2 & & 12,0 & 13,0 & 11,0 \\
\hline Iprodione,50 $(200\rangle$ & 0,0 & 10,0 & 13,8 & & 13,5 & $12, \sigma$ & 12,3 \\
\hline Benomyl. $50(100)$ & 10,4 & 10,3 & 13,7 & & 13,2 & 12,0 & 12,3 \\
\hline Benomyl, so (200) & 10,4 & 0,8 & 13,8 & & $13 \cdot 1$ & 13,3 & 12,7 \\
\hline Iprod. (50) +Thir. (150) & 10,0 & 10.4 & $13, \sigma$ & & 13,2 & 13,2 & 12,0 \\
\hline Iprod. (100)+Thir. (300) & 10,7 & 10,3 & 12,0 & & 12,8 & 13,3 & 13,5 \\
\hline MEDDAS & 10,1 & 0,0 & 13,0 & & 13,3 & 13,0 & 12,5 \\
\hline
\end{tabular}

O teor de água das sementes durante o periodo experimental variou em média de 9,9 a $13,6 \%$, condiföes estas favoráveis para o armazenamento das sementes de ervilha, bem como para a reduçåo da atividade dos microorganismos.

\subsubsection{Sanidade das sementes}

Os dados nåo foram submetidos a análise estatistica, entretanto procurou-se verificar as possiveis tendéncias, sendo que as médias obtidas no exame de sanidade das sementes dos dois lotes desta cultivar se encontram nas Tabelas 24 e 25 . 


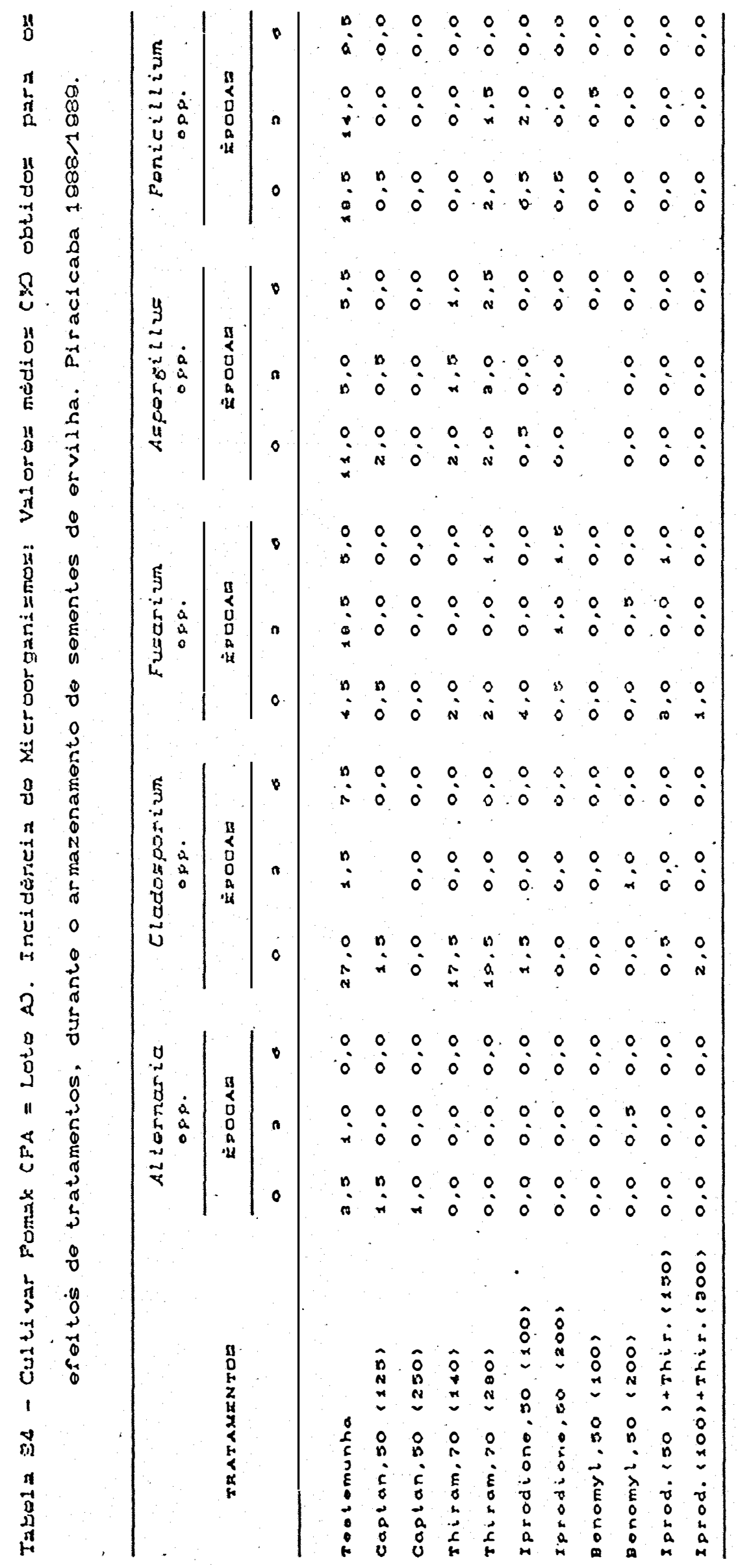

76. 
77.

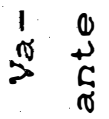

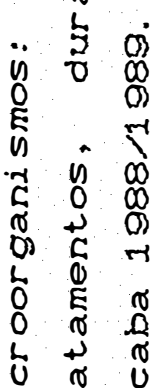

से

D.

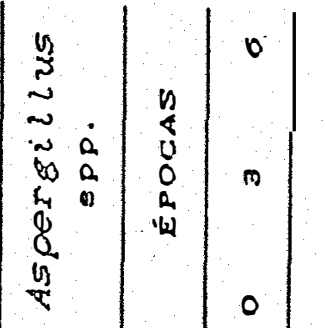

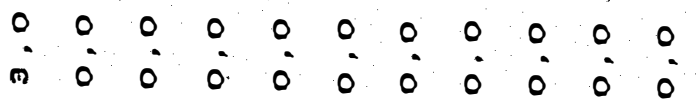

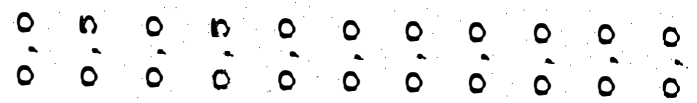

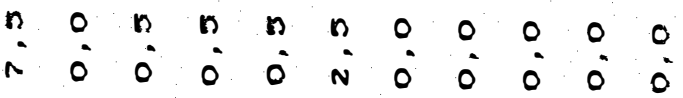

$\mid \begin{array}{llllllllllll}n & 0 & 0 & 0 & 0 & 0 & 0 & n & 0 & n & 0 \\ 0 & 0 & 0 & 0 & 0 & 0 & 0 & 0 & 0 & 0 & 0\end{array}$

$\begin{array}{lllllllllll}n & 0 & 0 & 0 & 0 & 0 & 0 & 0 & 0 & 0 & 0 \\ N & 0 & 0 & 0 & 0 & 0 & 0 & 0 & 0 & 0 & 0\end{array}$

$\begin{array}{lllllllllll}n & 0 & 0 & n & 0 & 0 & n & 0 & 0 & 0 & 0 \\ N & 0 & 0 & 0 & 1 & 0 & 0 & 0 & 0 & 0 & 0\end{array}$

$\begin{array}{ccc}0 & n & 1 \\ -1 & 0 & \\ 0 & + & 0 \\ c & 0 & 5 \\ 0 & 0 & -1 \\ 0 & 4 & -1 \\ -1 & 0 & b \\ 0 & n & 0\end{array}$

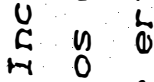

$\therefore \sigma \frac{0}{0}$

$\widehat{\infty} \frac{1}{0}$

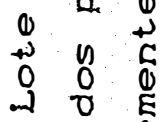

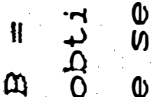

a. 0

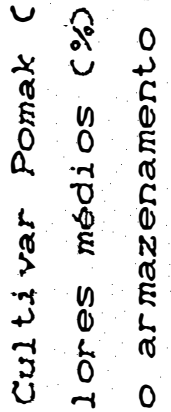

$\ln _{0}$

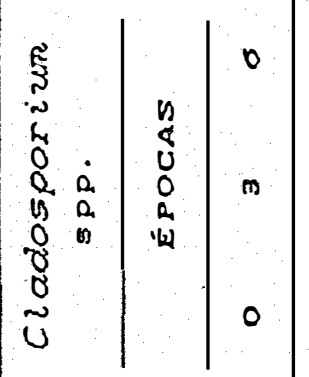

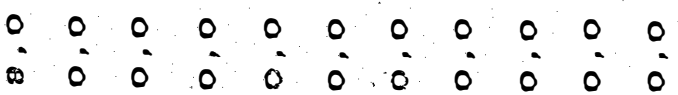

$\because \begin{array}{lllllllllll}0 & 0 & 0 & 0 & 0 & 0 & 0 & 0 & 0 & 0 \\ & 0 & 0 & 0 & 0 & 0 & 0 & 0 & 0 & 0 & 0\end{array}$

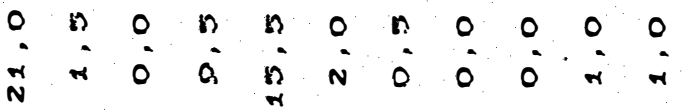

\begin{tabular}{l|l|l|lllllllllll}
0 & 0 & 0 & 0 & 0 & 0 & 0 & 0 & 0 & 0 & 0 & 0 & 0 \\
$\tilde{h}$ & 0 & 0 & 0 & 0 & 0 & 0 & 0 & 0 & 0 & 0 & 0
\end{tabular}

$\begin{array}{lllllllllll}0 & 0 & 0 & 0 & 0 & 0 & 0 & 0 & n & 0 & 0 \\ 0 & 0 & 0 & 0 & 0 & 0 & 0 & 0 & 0 & 0 & 0\end{array}$

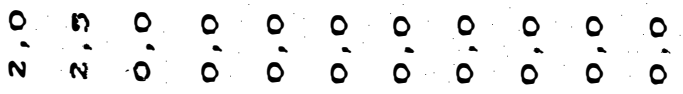

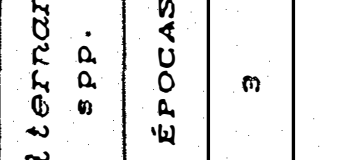

$+$

0

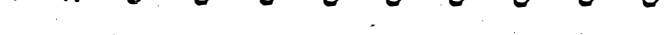

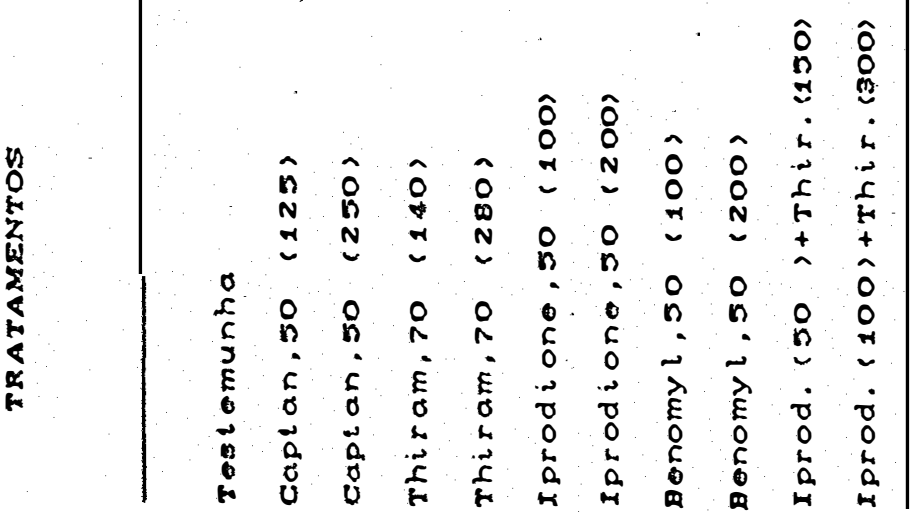


78.

\subsubsection{Lote PA}

Além dos microorganismos descritos na Tabela 24, O fungo Botrytis spp. também foi recuperado apenas nas sementes não tratadas, com incidencia de $0,5 \%$, sendo que aos trés meses após o armazenamento este fungo teve sua incidência reduzida a zero. Todos os tratamentos fungicidas proporcionaram um excelente controle, já no inicio do armazenamento.

Com relação a Alternaria spp., verificou-se uma redução do fungo com o decorrer do armazenamento, confirmando os resultados obtidos com o cultivar Mikado e também por CUNHA et alii, (1987) e NOVEMBRE, (1987). Quanto ao controle deste patógeno, com exceção do fungicida captan, todos os demais eliminaram o fungo já no inicio do armazena-mento. Este produto só controlou o patógeno após trés meses de armazenamento, onde a incidencia do mesmo foi menor.

Para o fungo Cladosporium spp., verificou-se uma alta incidencia nas sementes năo tratadas, no inicio do armazenamento. Observou-se também uma reduçăo do microorganismo com o decorrer do armazenamento, mas ainda com uma incidência considerável no final do mesmo. Resultados semelhantes foram encontrados no cultivar Mikado. Todos os fungicidas, com exceção do Thiram permitiram um excelente controle do microorganismo já no inficio do armazenamento, contrariando parte dos resultados observados por ELLIS et alii (1975), os quais obtiveram bons resultados no controle 
79.

deste patógeno utilizando o fungicida Thiram.

Quanto ao fungo Fusarium spp. , observou-se nas sementes não tratadas um aumento após os trés meses de armazenamento, reduzindo posteriormente aos seis meses. Os fungicidas Captan (250 g de i.a/100 kg de sementes) e Benomyl proporcionaram uma redução a zero do microorganismo logo no infcio do armazenamento. Esie último produto tem sido considerado bastante eficiente no controle deste patógeno (ELLIS et alii, 1975; FURLAN et ai ii, 1985; NOVEMBRE, 1987 ). Aos três meses de armazenamento, com exceção de Iprodione (200 $\mathrm{g}$ de $1 . \mathrm{a} / 100 \mathrm{~kg}$ de sementes) e Benomyl (200 $\mathrm{g}$ de . i. a $100 \mathrm{~kg}$ de sementes), todos os demais fungicidas reduziram à incidencia deste microorganismo a zero. Aos seis meses, estes mesmos dois produtos nas dosagens citadas, bem como Iprodione + Thiram $(50+150 \mathrm{~g}$ de i.a/100 kg de sementes) também não conseguiram eliminar totalmente o patógeno.

Os fungos de armazenamento, Aspergillus spp. e Penicillum spp., apresentaram uma redução durante o período de armazenamento. Além de Thiram, também observado no cultivar Mikado, os fungicidas Captan e Iprodione nas dosagens menores não foram tão eficientes no controle de Aspergilus spp. quanto aos demais tratamentos. Estes mesmos produtos também se mostraram menos eficientes no controle de Penicillium spp. 
80.

\subsubsection{Lote PB}

Neste lote, além dos microorganismos apreserztados na Tabela 25, observou-se uma incidencia de $1,0 \%$ de Rhizoctonia solani, sendo que aos trés meses de armazenamento, esta incidéncia foi reduzida a zero.

O fungo Alternaria spp., só foi observado nas sementes não tratadas e naquelas tratadas com Captan $125 \mathrm{~g}$ de i.a $/ 100 \mathrm{~kg}$ de sementes na primeira época. Já na segunda época, observou-se uma pequena incidência deste patógeno nas sementes tratadas com Benomyl $1200 \mathrm{~g}$ de i.a/100 kg de sementess. Os demais tratamentos proporcionaram um excelente controle do patúgeno.

Com relação a Cladosporium spp., observou-se uma alta incidência no inf́cio do armazenamento, para o material não tratado com uma redução média durante o mesmo. Aos trés meses de armazenamento, não foi observada recuperação do microorganismo nos tratamentos fungicidas. Somente os

fungicidas Captan (250 $\mathrm{g}$ de i.a/100 kg de sementes) e Benomyl reduziram a incidencia a zero logo no inf́cio do armazenamento.

Por outro lado, com relação ao patógeno Fusarium spp. observou-se um pequeno aumento da sua incidencia com o decorrer do armazenamento, sendo que para este lote, com exceção de Thiram e Iprodione c200 g de i.a/100 kg de sementes), todos os demais tratamentos proporcionaram um excelente controle no inicio do armazenamento. Verificou-se 
81.

ainda, aos seis meses, uma pequena incidência nas sementes tratadas com Benomyl e Iprodione + Thiram nas dosagens menores.

Quanto aos fungos de armazenamento, só foi observada neste lote a presença de Aspergillus spp., verificando-se ainda uma redução deste patógeno com o decorrer do armazenamento. Com exceção do fungicida Thiram e Captan (250 g de i.a $100 \mathrm{~kg}$ de sementes), todos os demais proporcionaram um excelente controle deste microorganismo já no inflio do perlodo de armazenamento.

\section{3. Consideraçôs Finais}

A análise geral dos resultados obt.idos, permi-tiu verificar que os dois cultivares apresentaram algumas caracteristicas em comum, tanto na qualidade fisiológica como na qualidade sanitária, sob o efeito dos diferentes tratamentos fungicidas ao longo do armazenamento.

Por ocasião do infcio do periodo experimental, ou seja, antes do armazenamento, os lotes dos dois cultivares apresentavam porcentagens de germinação muito semelhantes, sendo observado uma maior diferença entre os dois lotes do cultivar Mikado.

O mesmo foi verificado no teste de primeira contagem de germinaçăo, onde os dois cultivares também se comportaram de forma semelhante, sendo que nos lotes dos mesmos já se podia observar uma separaçăo no vigor das sementes. 
82.

Dentro ainda da qualidade inicial das sementes utilizadas dos dois cultivares, observou-se que no cultivar Mikado os resultados sempre apontaram para um maior vigor. O teste de envelhecimento acelerado, desenvol vido para estimar - potencial de armazenamento de um determinado lote de sementes, já identificava o cultivar Mikado como o mais promissor. Notou-se ainda com este teste uma diferença entre os lotes apenas no cultivar Mikado.

Resultados semelhantes tamberm foram evidenciados pelos testes de condutividade elétrica e emergéncia das plantulas em campo, onde o cultivar Mikado sempre se comportou com um maior desempenho. Para o teste de condutividade elétrica, os lotes dos cultivares se comportaram diferentemente, com uma superioridade, dentre eles, dos lotes MA e PA. O grau de umidade das sementes nos diferentes lotes se mostrou, no infcio do armazenamento praticamente o mesmo.

Quanto a qualidade sanitária das sementes no inficio do periodo experimental, houve nos lotes certas diferenças quanto a uma maior ou menor incidencia dos microorganismos, sendo que o cultivar Pomak se apresentou como o de melhor sanidade.

Analisando os resultados referentes à qualidade fisiológica das sementes dos dois cultivares lógo após os referidos tratamentos fungicidas, portanto ainda no infcio do armazenamento, verificourse que não houve efeitos positivos destes às sementes, sendo que em alguns casos estes até 
83.

se comportaram negativamente, permitindo assim considerar algum efeito fitotóxico. Quanto ao controle dos microorganismos associados às sementes de ervilha, verificou-se que a maioria dos fungicidas utilizados quando não eliminaram totalmente tais patógenos, reduziram a niveis bastante baixos. Assim sendo, pode-se ponderar na primeira época de estudo que, apesar dos fungicidas utilizados no presente trabal ho, com suas respectivas dosagens, não terem conseguido melhorar a qualidade fisiológica dos diferentes lotes, sem dúvida alcançaram excelentes resultados na recuperação da qualidade sanitária das sementes de ervilha. Comparando os resultados dos diversos testes após os trés meses de armazenamento, pode-se agora verificar diferentes respostas aos tratamentos fungicidas nos quatro lotes estudados.

- teste padrão de germinação foi o único o qual não se obteve resposta significativa com os tratamentos fungicidas aos trés meses após o armazenamento. Este teste nem sempre nos permite verificar tais diferenças, visto que - mesmo é realizado sob condiçöes de ambiente que garantam o máximo do potencial fisiológico, pois praticamente todas as variáveis são controladas.

Quanto ao teste de primeira contagem de germinação, considerado uma variaçăo do teste padrão de germinação, nos dá um indicativo do vigor, já que constatamos nele a rapidez da germinaçăo das sementes. Pelos resultados obtidos, verificou-se que houve uma tendencia dos 
84.

produtos fungicidas em diminuir a velocidade de germinação das sementes, de forma ainda mais acentuada quando. em dosagens maiores. A mistura dos fungicidas Iprodione + Thiram, bastante utilizados pelos produtores de ervilha, se mostrou fitotóxico no referido teste, quando na dosagem de $100+300 \mathrm{~g}$ de i. a/100 kg de sementes.

Por sua vez, o teste de envelhecimento acelerado, teste este utilizado, dentre outros, para avaliar a longevidade de um lote de sementes, mostrou um efeito benéfico da maioria dos fungicidas na manutenção do vigor das sementes, atenuando assim os efeitos da deterioração. Verificou-se tamberm neste teste uma maior resposta aos fungicidas, aos tres meses de armazenamento, no cultivar Pomak, onde o vigor das sementes sabidamente era inferior.

outro teste utilizado na determinação do vigor das sementes, o teste de condutividade elétrica, năo nos permitiu verificar um efeito positivo dos tratamentos fungicidas nesta segunda época. Entretanto, observou-se uma certa tendéncia do fungicida Iprodione em melhorar o vigor das sementes nos dois cultivares testados.

Além das informaçzes recebidas através dos testes de laboratório, o teste de emergencia das plantulas em campo retrata com uma maior clareza o desempenho das sementes no campo, já que o objetivo final é o estabelecimento da cultura. Assim, os resultados apontaram, na segunda época de estudo, época esta também năo adequada ao cultivo de ervilha, um melhor desempenho elou uma melhor proteção 
85.

proporcionado por aqueles fungicidas considerados de amplo espectro de açăo, como Captan e Thiram; e também pela mistura Iprodione + Thiram, que como citado anteriormente apresenta um efeito sinergístico no controle de certos microorganismos. Em média, verifica-se nesta segunda época, uma menor emergéncia das plantulas em campo nos dois cultivares; isto provavelmente se deve a um maior ataque de microorganismos do solo, já que as sementes tratadas estavam praticamente isentas de microorganismos.

No final do periodo experimental, ou seja, após seis meses de armazenamento identificou-se o fungicida Captan na dosagem de $250 \mathrm{~g}$ de i.a/100 $\mathrm{kg}$ de sementes como fitotóxico, já que nos dois cultivares foi observado uma reduça significativa na porcentagem de germinaçăo das sementes tratadas com o produto. Como nas demais épocas estudadas, não se observou um efeito considerável na porcentagem de germinação das sementes tratadas com os produtos fungicidas. Resultados semelhantes também foram observados no teste de primeira contagem de germinação.

Entretanto, quando se observa os resultados obtidos no teste de envelhecimento acelerado, nota-se que a maioria dos fungicidas garantiram ou até elevaram o vigor das sementes. Nos dois cultivares, o fungicida Captan C250 g de i.a/100 kg de sementes) reduziu o vigor das sementes.

Quanto ao teste de condutividade elétrica, não ficou muito evidente a resposta ao tratamento fungicida, embora tenha sido observado uma tendencia, durante todo o 
86.

armazenamento das sementes tratadas com os fungicidas Iprodione e Benomyl, em apresentar um melhor vigor.

Na época normal de semeadura no campo, apesar de não ter sido verificado diferença estatistica no cultivar Mikado, a maioria dos tratamentos fungicidas conseguiu elevar o desempenho a campo das sementes nos dois cultivares testados, observando ainda um efeito mais proeminente no. cultivar de menor vigor.

Considerando os resultados deste trabalho, podemos inferir que a utilização destes fungicidas em sementes antes do armazenamento torna-se bastante interessante, visto - controle dos diversos microorganismos, sejam estes de campo ou armazenamento. Por outro lado, apesar dos fungicidas testados apresentarem em alguns casos fitotoxidez as sementes em laboratório, este dano é amenizado ou mesmo nulo quando as sementes são semeadas em.ćampo. 
87.

5. CONCLUSÖES

A análise dos resultados do presente trabalho permitiu as seguintes conclusbes:

- Os efeitos favoráveis dos tratamentos fungicidas na germinaça e vigor das sementes se manifestaram principalmente em sementes de menor qualidade fisiológica;

- As tendências de efeitos fitotóxicos em sementes por alguns fungicidas, observados em laboratório, foram amenizados ou mesmo sumprimidos quando estas foram semeadas em campo;

- A maioria dos fungicidas testados exerceu um excelente controle dos prineipais fungos de campo associados as sementes, bem como nos fungos de armazenamento, garantindo assim uma melhoria na. qualidade sanitária das sementes;

- Os produtos fungicidas de amplo espectro de açăo, como Captan e Thiram, assim como a mistura Iprodione + Thiram proporcionaram, na epoca normal de semeadura uma maior emergencia de plantulas no campo. 
88.

\section{REFERENCI AS BIBLIOGRAFICAS}

AGARWAL, V.K. \& SINCLAIR, J.B. Principles of seed pathology. Boca Raton, C.RC. Press, 1987. 2 v.

ANDERSON, J.D. \& BAKER, J.E. Deterioration of seeds during aging. Phytopathology, 73(2): 321-325, 1983.

ASSOCIATION DE OFFICIAL SEED ANALYSTS. Seed vigor testing handbook. Lansing, Contrib. nㅇ 32 to the Handbook on Seed Testing, 1983. 88p.

BALARDIN, R.S. \& LOCH, L.C. Efeito de thiram sobre a germinação de sementes de centeio e aveia. Revista Brasileira de Sementes, $9(1): 113-117,1987$.

BAYLIS, G.T.S. Fungi which cause pre-emergence injury to garden peas. The Annals of Applied Biology, 28(3): $210-218,1941$.

BAYLIS, G.T.S.; DESHPANDE, R.S.; STOREY. I.F. Effect of seed treatment on emergence of peas. Ann. appl. Biol, 30: $19-26,1943$.

BI IIENCOURT, C. ; OLIVEIRA, C. ; REIFSCHNEIDER, F.J.B. ; TATEISHI, N.Y. Levantamento das doenças de ervilha CPisum satiuun L.) no Distrito Federal. Fitopatologia Brasileira, $10(1): 185-194,1985$. 
89.

BOLKAN, H.A.; SILVA, A.R. ; CUPERTINO, F.P. Fungi associated with soybean and bean seeds their control in Central Brazil. Plant Disease Reporter, 60(6): 545-548, 1976.

BORElli, A.; CARVALHO, N. M.; BARRETO, M. ; FERNANDES, N. G. ; KRONKA, S.N. Efeito do tratamento fungicida em sementes de soja (Glycine max (L.) Merril) de diferentes niveis de vigor sobre a emergéncia e vigor das plántulas. Summa Phytopathologica, 4(7), 1978 . (resumos).

BRASIL. MINISTÉRIO DA AGRICULTURA. Departamento de Produção Vegetal. Divisão de Sementes e Mudas, 1980. Regras para análise de sementes. Brasilia, 1980, $188 \mathrm{p}$.

CAFE FILHO, A.C.; LOPES, C. A. ; DUSSI, A. N. ; REIFSCHNEIDER, F.J.B.; CHARCHAR, J.M. Principais doenças da ervilha no Brasil e seu controle. Informe Agropecuário, 14(158): 38-45. 1989.

CAFE FILHO, A.C.; REIFSCHNEIDER, F: J.B. ; GIORDANO, L. B. ; SILVA, C. B. Avaliação de genótipos quanto a resistência à Rhizoctonia solani. Fitopatologia Brasileira, 11(12): 294,1980 (resumos).

CARVALHO, N.M. \& NAKAGAHA, J. Sementes: Ciencia, Tecnologia - Produçăo, $3^{\circ}$ ed. Campinas, Fundação Cargill, 1988. $424 p$.

CHRISIENSEN, C.M. Microflora and seed deterioration. In: ROBERTS, E. H. ed. Viability of seeds. London, Syracuse Univ. Press. cap. 3, p. 59-93, 1972.

CHRISIENSEN, C.M. LoSS of viability in storage microflora Seed Science and Technology, 1: 547-562, 1973. 
90.

CHRISTENSEN, C.M. \& KAUFMANN, H. J. Grain storage: the role of fungi in quality loss. Minneapolis, University of Minnesota, 1963. 153p.

CICERO, S.M.; CHAMMA, H.M.C.P. ; MORAES, M.H.D. Tratamento fungicida em sementes de milho. Piracicaba, ESALQ/Departamento de Agricultura, 1989. 14p. (Relatório Técnico).

CUNHA, M.M. ; REIFSCHNEI DER, F.J.B. ; DELLA VECHIA, P.T. Aspectos fitossanitários na produção de sementes de cenoura. Horticultura Brasileira, 5(2): 11-14, 1987.

DELOUCHE, J.C. ; MATTHES, R.K.; DOUGHERTY, G.M. ; BOYD, A.H. Storage of seed in sub-tropical and tropical regions. Seed Sci. \& Technol., 1: 671-700, 1973.

DHINGRA, O.D. ; MUCHOVEJ, J.J.; CRUZ FILHO, J. Tratamento de sementes (Controle de Patógenos), Viçosa, Imprensa Universitária, $1980,121 \mathrm{p}$.

EDJE, O.T. \& BURRIS, J.S. Effect of soybean seed vigor on field performance. Agron. J., 63( 4): 536-538, 1971.

Ellis, M. A.; GALVEZ, G.E.; SINClAIR, J.B. Efecto de trés fungicidas sobre la germinación de semilla infectada de frijol (Phaseolus vulgaris). Turrialba, 26( 4): 399-402, 1976.

ELLIS, M.A.; ILYAS, M.B.; SINCLAIR, J.B. Effect of three fungicides on internally seed-borne fungi and germination of soybean seeds. Phytopathology, 65: 553-556, 1975.

ELLIS, M. A. \& PASCHAL, E. H. Effect of fungicide seed treatment on internally seed-borne fungi, germination and field emergence of pigeon pea (Cajanus cajan). Seed Sci. \& Tecnol., 7: 75-81, 1979. 
91.

FIELDS, R. H. \& KING, T.H. Influence of storage fungi on deterioration of stored pea seed. Phytopathology, 52: $336-339,1962$.

FORSBERG, J.L.; OLSON, E.; BINKLEY, A.M. Experiments with pea seed treatments in Colorado. Phytopathology, 34: $753-759,1944$.

FURLAN, S.H.; AMARAL, H.M. ; MORAES, M.H.D.; BUENO, J.T.; MENTEN, J.O.M. Efeito de quatro fungicidas na incidencia de colletotrichum gloesporioides e Fusarium spp. em sementes de algodão CGossypium hirsutum L.) In: Congresso Brasileiro de Sementes, 4 Brasilia, 1985. Resumos. Brasilia, ABRATES, 1985 , p. 144.

GILIOLI, J.L. ; PEREIRA, A. G. ; ALMEIDA, A.M.R. ; COSTA, N.P. Efeito de profundidade de semeadura e do tratamento de sementes de soja com fungicida, sobre. a emergéncia, em solo com diferentes condiçôs de umidade. Fitopatologia Brasileira, 6: 87-92, 1981 .

GRUPO PAULISTA DE FITOPATOLOGIA, Coord. Guia de Fungicidas Agricolas. Piracicaba, Livroceres, 1986, $281 \mathrm{p}$.

HAGEDORN, D.J. Compendi um of Pea Diseases. Madison, The American Phytopathological Society. 1984. 57p.

HALLOIN, J.M. Microorganisms and seed deterioration. In: MCDONALD, M.B. \& NELSON, C.J., ed. Physiology of seed deterioration. Madison, C.SSA Spec. Pub. no. II, cap. 5, p. 89-99. 1986.

HARMAN, G.E. Deterioration of storage pea seed by Aspergillus ruber: extraction and properties of a toxin. Phytopathology, 62: 206-208, 1972. 
92.

HARMAN, G.E. \& NASH, G. Deterioration of stored pea seed by Aspergillus ruber: evidence for involvement of a toxin. Phytopathology, 62: 209-212, 1972.

HARMAN, G.E. \& PFLEGER, F.L. Pathogenecity and infenction sities of Aspergillus species in stored seeds. Phytopathology, 64: 1339-1344, 1974.

HARRINGTON, J.F. Seed storage and longevity. In: KOZLOWSKI, T.T., ed. Seed biology. New York, Academic Press, 1972 , v. 3. p. $145-245$.

hauagge, C.A.C. \& SIlva, A. C. da. Efeito do tratamento de semente com. fungicida sobre a emergencia em campo e doenças foliares da cevada. Revista Brasileira de Sementes, 2(1): 107-112, 1980 .

HEYDECKER, W. Vigour. In: ROBERTS, E. H. ed. Viability of seeds. London, Syracuse Univ. Press., cap. 8, p.209-252, 1972 .

KAISER, W. J. \& HANNAN, R. M. Seed-treatment fungicides for control of seedborne Ascochyta lentis on Lentil. Plant Disease, 71: 58-62, 1987.

KAISER, w.J. \& HANNAN, R.M. Seed-transmission of Ascochyta rabiei in chickpea and its control by seed-treatment fungicides. Seed Sci. e Tecnol., 16: 625-637, 1988.

KRAFT, J.M. The influence of seedling exudates on the resistance of peas to Fusarium and Pythium root rot. Phytopathology, 64: 190-193, 1974.

KRAFT, J.M. Field and greenhouse studies on pea seed treatments. Plant Disease, 66(9): 798-800, 1982. 
93.

LEACH, L.D. \& SMITH, P.G. Effect of seed treatment of protection, rate of emergence, and growth of garden peas. Phytopathology, 35t $191-206,1945$.

LOCKE, J.C. ; PAPAVIZAS, G.C. ; LEMIS, J.A. Seed treatment with fungicides for the control of Phytium seed rot of peas. Plant Disease Reporter, 63(9): 725-728, 1979.

LOEFFLER, T.M.; TEKRONY, D. M. ; EGLI, D. B. The bulk conductivity tests as on inbicator of soybean seed quality. Jownal of seed technology, 12(1): 37-53, 1988.

LORIA, R.' \& LACY, M. L. Mechanism of increased susceptibility of bleached pea seeds to seed and seedling rot. Phytopathology, 69(6): 573-575, 1979.

MACHADO, J. da. C. Patologia de Sementes: Fundamentos e Aplicaçőes, Brasflia, Ministério da Edutaçăo, 1988, $107 \mathrm{p}$.

MADEIRA, M. C.B.; REIFSCHNEIDER, F.J.B.; CAFE FILHÖ, A. Eficisncia e fitotoxidez de fungicidas no tratamento de sementes de lentilha para o controle de Rhizoctonia solani, 1986. Horticultura Brasileira, 6(1): 36-37, 1988.

MAUDE, R.B. Pea seed. infection by Mycosphaerella pinodes and Ascochyta pisi and its control by seed soaks in thiran and captan suspensions. Ann. appl. Biol., 57: $193-299$, 1966.

MAUDE, R.B. \& KYLE, A. M. Seed treatments with benomyl and other fungicides for the control of Ascochyta pisi on peas. Ann. appl. Biol., 66: 37-41, 1970.

MAUDE, R.B.; PRESLEY, A.M.; LOVETT, J.F. Demonstration of the adherence of thiram to pea seeds using a rapid method of spectrophotometric analysis. Seed Sci. \& Technol., 14: $361-369,1986$. 
94.

MARCOS FILHO, J.; C.ICERO, S.M. ; SILVA, W.R. da. Avaliaçăo da qualidade das sementes. Piracicaba, FEALQ. 1987, 230p.

MARCOS FILHO, J.; PERRI JUNIOR, J. Efeitos de tratamentos fungicidas sobre a germinaçăo e o vigor de sementes de algodão (Gossypium hirsutum L.), arroz (Oryza sativa L.) e feijăo (Phaseolus vulgaris L.). O solo, 69(1): 35-42, 1977.

MARCOS FILHO, J. \& SHIOGA, P.S. Tratamento fungicida de sementes de soja no teste de envelhecimento rápido, Rev. Agric., 56(3): 163-172, 1981 .

MARCOS FILHO, J.; SOUZA, F.H. D. Conservaçăo de sementes de soja tratadas com fungicidas. Anais da E.S.A. "Luiz de Queiroz", XL: 180, 201, 1983.

MENTEN, J.O.M.; MENDES, B.M.J. Efeito do genótipo e tratamento químico na incidência de microorganismos em sementes de feijão (Phaseolus vulgaris L.). o solo, 74: 7-12, 1982.

MINTON, E.B. \& LEWIS, J.A. Effect of fungicide seed treatments and seed quality. on seedling diseases and yield of cotton. Plant Disease, 66: 832-835, 1982.

MIRANDA, T.R. \& SOUZA, F.A. Efeito do tratamento com fungicida thiabendazol na germinaçăo de sementes de soja. Rev. Bras. Sem., 2(1): 35-42, 1980.

MORAES, M.H.D. de. Efeito do estádio de desenvolvimento, condiç̧̄es e período de armazenamento na sanidade de sementes de soja (Glycine max (L.) Merril). Piracicaba, 1989. CMestrado - Escola Superior de Agricultura "Luiz de Queiroz"NSPJ. 
95.

NEERGAARD, P. Seed Pathology. MacMillan Press, Londres, Inglaterra. vol. I, 1979. 850p.

NOVEMBRE, A. D. da L.C. Tratamento fungicida e conservação de sementes de feijoeiro (Phaseolus vulgaris L.), Piracicaba, 1987. 147p. CMestrado - Escolha Superior de Agricultura, "Luiz de Queiroz" MUSP).

PFLEGER, F.L. ; GROTH, J.V. ; REILING, T.P. The assessment of fungicides for control of pea root rot in the field. Plant Disease Reporter, 60(4): 317-321, 1976.

PHIPPS, P.M. Soybean and peanut seed treatment: new developments and.needs. Plant Disease, 68(1): 76-77, 1984.

PITA, A. H. C. ; REIFSCHNEIDER, F. J.B. ; GIORDANO, L. B. ; CORDEIRO, C.M. I. Tratamento. de sementes de ervilha para o controle de Rhizoctoniose. Fitopatologia Brasileira, 11: $647-654,1986$.

POWELL, A.A. \& MATTHWES, S. Deteriorative changes in pea seeds (Pisum sativum L.) stored in humid or dry conditions. Journal of Experimental Botany, 28(102): 225-234, 1977.

RICHARDSON, L.T. Synergism between chloroneb and thiram applied to peas to control seed rot and damping-off by Phytium ultimum. Plant Disease Reporter, 57(1): 3-6, 1973.

RICHARDSON, M.J. An Annotaded List of Seed-Borne Diseases. Survey. Engl and, Con. Myc. Inst., 1979. 320p.

RICHARDSON, M.J. An Annotaded List of Seed-Borne Diseases CSuplement 1), 3ํㅡ ed., Zurich, Switzerland. ISTA, 1981. $79 p$. 
96.

ROBERTS, E. H. \& ABDALLA, F.H. The influence of temperature, moisture, and oxygen on period of seed viability in barley, brad beans, and peas. Ann. bot., 32: 97-117, 1968.

ROWE, R.C. Ridomil, Ronil on and Rovral - News tools for vegetable disease control. Plant Disease, 67(12): 1391, $1392,1983$.

SANTOS, J.R.M. Doenças da cultura da ervilha - CNPH/EMBRAPA, Brasilia, 1989. (no prelo).

SHORT, G.E. \& LACY, M.L. Germination of Fusarium solani f. sp. pisi chl amydospores in the spermosphere of pea. Phytopathology, 64: 558-562, 1974.

SHORT, G.E. \& LACY, M. L. Carbohydrate exudation from pea seeds: Effect of cultivar, seed age, seed color and temperture. Phytopathology, 66: 182-187, 19376.

SILVA, H.R. Relações entre disponibilidade de água tratamento fungicida e germinação de sementes de milho czea mays L.j Piracicaba, 1989. 113p. CDoutorado - Escola Superior de Agricultura "Luiz de Queiroz"

TANAKA, M. A. \& CORREA, M.U. Influência de Aspergillus e Penicillium no armazenamento de sementes de feijão CPhaseoius vulgaris L.J. Fitopatologia Brasileira, 6: 451-456, 1981.

THAPLIYAL, P.N. \& SINCLAIR, J.B. Uptake of three systemic fungicides by germinating soybean seed. Phytopathology, 60: 1373-1375, 1970 .

VAN TOAI, T.T.; MCDONALD, J.R.; STABY, G.L. Cultivar, fungicide, seed treatment and storage environment interactions on carry-over soybean seed quality. Seed Sci. \& Technol, 14: 301-312, 1986. 
97.

WALKER, J.C. ; DELHICHE, E. J. ; SMI TH, P. G. Pea seed treatment with chemical dusts. Journal of Agricultural Research, $61(2): 143-147,1940$.

WETZEL, M. M. V. da S. Fungos do Armazenamento. In: SOAVE, J. \& WETZEL, M.M.V. da S. Patologia de Sementes, Campinas, Fundação Cargil1, cap. 9 , p.260-275. 1987.

WINDELS, C.E. \& KOMMEDAHL, T. Factors affecting Penicillium oxalicum as a seed protectant against seedling blight of pea. Phytopathology, 68: 1656-1661. 1978.

WINDELS, C.E. \& KOMMEDAHL, T. Pea cultivar effect on seed treatment with Penicillium oxalicum in the field. Phytopathology, 72(5): 541-543, 1982. 